\title{
CORRELATION OF AES FY 1978 PROGRAM WITH ENERGY-RELATED ENVIRONMENTAL RESEARCH NEEDS
}

\author{
Prepared by
}

Environment and Safety Group

August 1976

Prepared for

Office of the Assistant Administrator for Environment and Safety ENERGY RESEARCH AND DEVELOPMENT ADMINISTRATION

Washington, D. C. 20545

Contract No. E(04-3)1101(PA-4)

ATOZ-76EV70004

Environment and Energy Conservation Division THE AEROSPACE CORPORATION 


\section{DISCLAIMER}

This report was prepared as an account of work sponsored by an agency of the United States Government. Neither the United States Government nor any agency Thereof, nor any of their employees, makes any warranty, express or implied, or assumes any legal liability or responsibility for the accuracy, completeness, or usefulness of any information, apparatus, product, or process disclosed, or represents that its use would not infringe privately owned rights. Reference herein to any specific commercial product, process, or service by trade name, trademark, manufacturer, or otherwise does not necessarily constitute or imply its endorsement, recommendation, or favoring by the United States Government or any agency thereof. The views and opinions of authors expressed herein do not necessarily state or reflect those of the United States Government or any agency thereof. 


\section{DISCLAIMER}

Portions of this document may be illegible in electronic image products. Images are produced from the best available original document. 


\section{CORRELATION OF AES FY 1978 PROGRAM \\ WITH ENERGY-RELATED \\ ENVIRONMENTAL RESEARCH NEEDS}

Prepared by

Environment and Safety Group

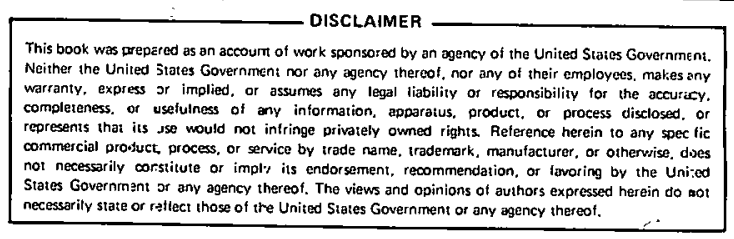

August 1976

ENVIRONMENT AND ENERGY CONSERVATION DIVISION

THE AEROSPACE CORPORATION

Germantown, Maryland 20767

$$
\text { Prepared for }
$$

Office of the Assistant Administrator for Environment and Safety ENERGY RESEARCH AND DEVELOPMENT ADMINISTRATION

Washington, D. C. 20545

Contract No. E(04-3)1101; PA-4 


\section{CONTENTS}

\section{Section}

1

ACKNOWIFDGMENT

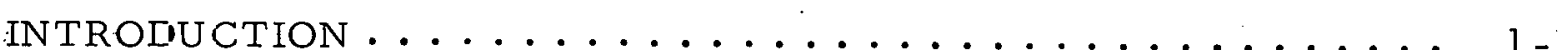

A. Identification of Energy-Related Environmental Is sues .... $1-1$

B. Correlation of AES FY 78 Research With the

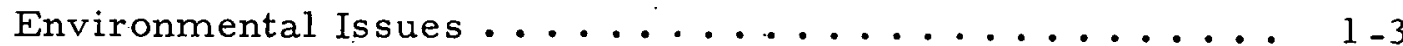

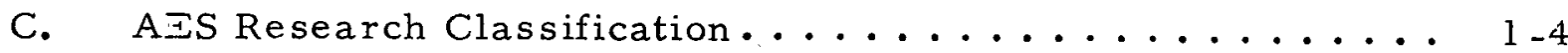

D. Tabulation of Results.......................... 1-5

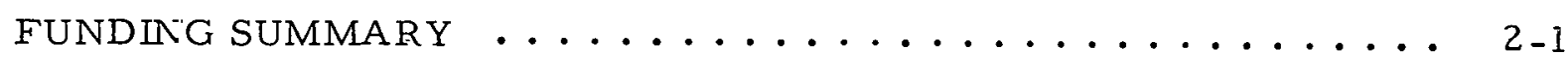

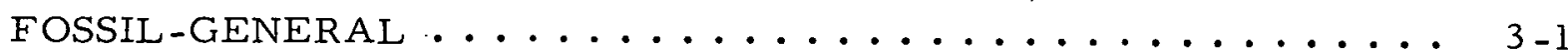

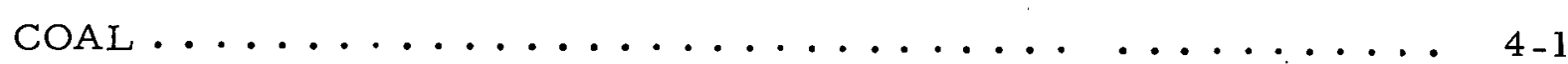

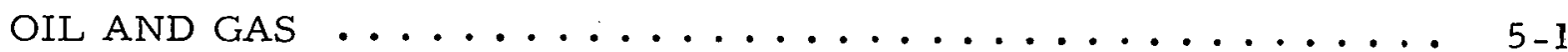

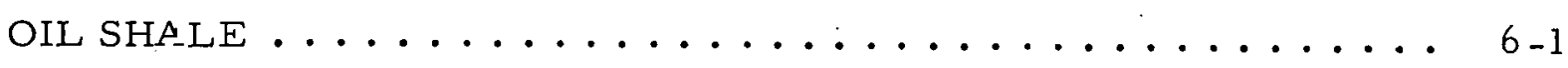

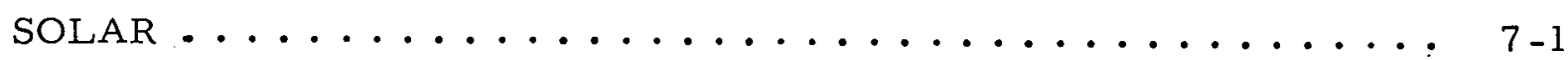

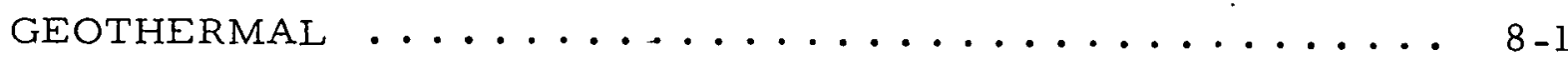

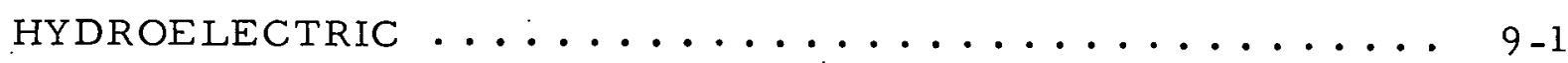

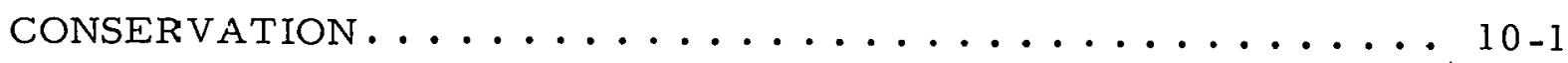

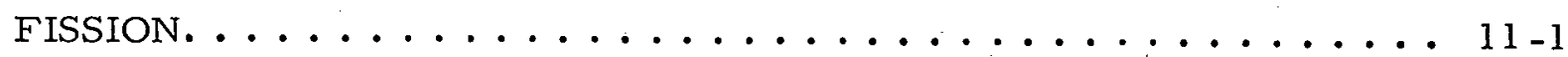

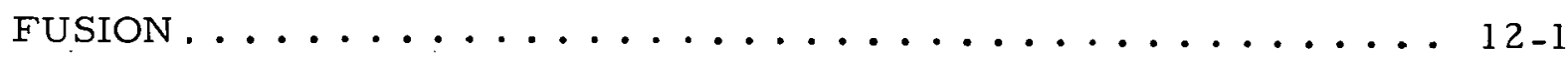

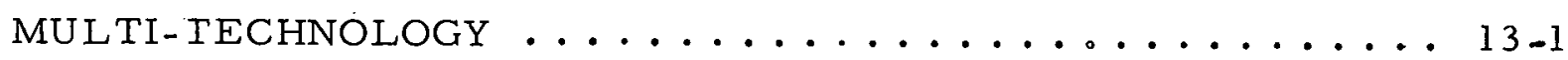

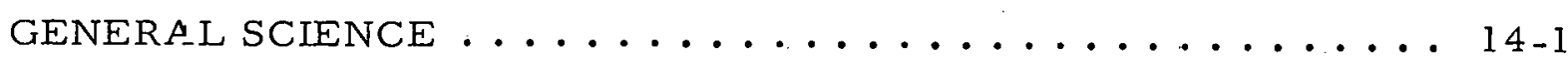

MEDICAL APPLICATIONS ........................... 15-1 


\section{A CKNOWLEDGMENT}

Appreciation is acknowledged for the assistance provided by the many AES divisional staf: members who contributed the data compiled in this report indicating the corre lation of projects in the AES FY 1978 program with the statemenis of environmental issues.

Mr. Solomon Rosenzweig of The Aerospace Corporation technical staff coordinated the preparation of this report. Messrs. Thornton Blanchard, Jr., James Chalmers, Frederick Collins, Elmer Fullenwider, Frank Hess, Franklin Nerman, and William Willis of The Aerospace Corporation technical staff are acknowledged for their contributions in compiling the material contained in this report.

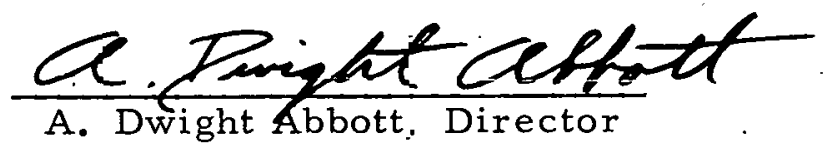

Planning Office

Environment and Safety Group

Approved:

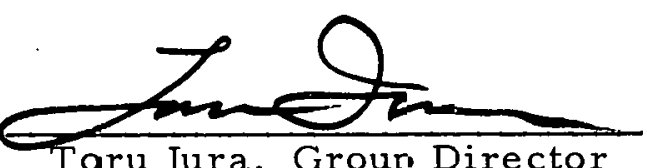

Toru Iura, Group Director Environment and Safety Group

Environment anc. Energy

Eonservation Iivision

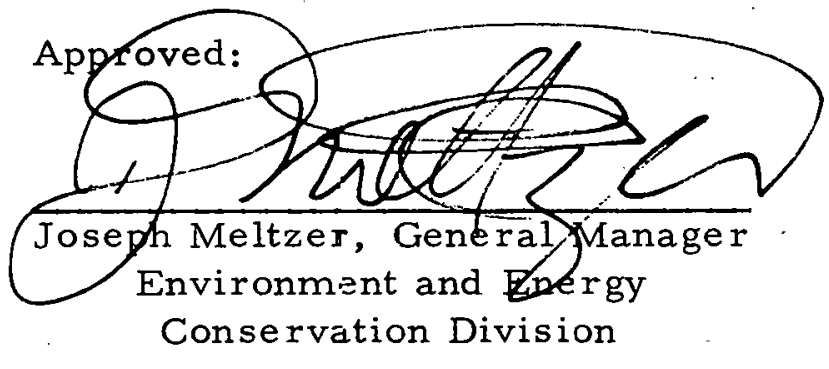




\section{SECTION 1}

\section{INTRODUCTION}

This report has a twa-fold objective: 1) to identify major energy-related environmental concerns, needs, and problem areas, and 2) to show the relationship of the planned FY 78 research program of the ERDA Assistant Administrator of Environment and Safety (AES) to those environmental issues. The document is organized into sections addressing each major energy form. Each section identifies environmental issues of an energy form and indicates the level of planned FY 78 AES research addressing each issue, thus delineating the links between environmental research and the needs of energy research, development, and demonstration (RD\&D).

\section{A. Identification of Energy-Related Environmental Is sues}

The environmental needs or issues compiled here for each energy form have been substantially drawn from published ERDA documents. The intent was not to establish an AES view of energy-related environmental needs, but to summarize the needs expressed throughout ERDA which AES research might support. The specific ERDA documents reviewed in order to identify expressed environmental needs, concerns, and problem areas are listed in Table 1-1. These documents include the ERDA National Plan, Program Approval Documents (PADs), and the AES Balanced Program Plan. Also included are environmental concerns expressed by the Office of Technology Assessment (OTA) and the Council on Environmental Quality (CEQ) in their reviews of ERDA environmental RD\&D activities. 
1. A National Plan for Energy Research, Development, and Demonstration: Creating Energy Croices for the Future 1976 (ERDA 76-1), Volume 1; The Flan, April 15, 1976

2. A National Plan for Energy Researç, Development, and Demonstration: Creating Energy Clooices for the Future, 1976 (ERDA 76-1), Volume 2; Program Implementation, February 6, 1976 Draft

2. Balanced Program Plan (BPP), Volume 1 - Overview and Summary (ERDA - 116), October 1975

4. Balanced Program Plan (BPP), Pre-iminary Guide for Implementation, February 1976

5. AES Program Approval Documents (PADs)

a. Biomedical and Environmental Research

b. Safety, Standards, and Compliance

c. Environmental Control Technology

6. AES written comments (letters to other AAs) on drafts of other Assistant Administrators' PAI's relative to Environment and Safety adequacy.

7. Program Approval Documents (PADs) of ERDA Assistant Administrators (AAs) responsible foz energy $R D \& D$ :

a. Fossil Energy Development
1) Coal
2) Petroleum and Natural Gas
3) Oil Shale

7. - continued

b. Solar, Geothermal, and Advanced Energy Systems Development

i) Solar Energy Development

2) Geothermal Energy Development

3) Physical Research

4) Fusion Power Research and Development

c. Conservation Research and Development

1) Transportation and Energy Conversion

2) Electric Energy Systems

3) Buildings Conservation

4) Conservation in Industry

5) Conservation Research and Technology

d. Nuclear Energy Developmert - Fission

1) Liquid Metal Fast Breeder Reactor Technology Program

2) Clinch River Breeder Reactor Program

3) Advanced Isotope Separation Technology

4) Light Water Breeder Reactor Program

5) Space Nuclear Systems

6) Uranium Enrichment and Resource Assessment

7) Special Materials Production

8) Fuel Cycle R\&D

8. Office of Technology Assessment's review of ERDA $76-1$ (Draft)

9. Council on Environmental Quality Report on 1975 Public Hearings, 9 April 1976

10. AES recognized environmental issues not mentioned by previous sources 
The environmental issues compiled from the se sources are listed in subsequent Sections of this report for each major energy form. The source from which each is sue was derived is shown in the

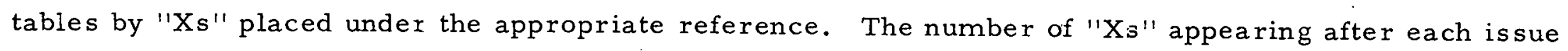
does not indicate a priority, but simply the number of source documents in which the issue was found. This type of presentation permits the reader to select those environmental issues associated with a specific reference(s) in which he may be interested.

Since the environmental issues have been drawn from a number of sources of varying detail, the compilation has overlaps as well as gaps in the content of the issues. Many of the statements of environmental issues are also lacking in detail or specificity desired by the planner attempting to formulate responsive research. No attempt was made by the authors to refine these issues. They have been compiled using statements conveying, as close as possible, the environmental need, concern, or problem expressed in the reference.

\section{B. Correlation of AES FY 78 Research With the Environmental Issues}

The planned AES FY 78 research program is composed of over 1,000 projects. This report correlates each of those projects with the previously mentioned environmental issues. The alignment of each individual project with specific statements of environmental issues was acccmplished by AES divisional staff members who were familiar with the planned research. The project-issue correlation for a small percentage of the projects, including all Environmental Control Technology Division projects, was accomplished by The Aerospace Corporation technical staff in order to fill data gaps resulting largely from project changes caused by evolution of the FY 78 research program. This project-issue correlation is a judgmental process which is made difficult in many instances by the lack of specificity in the statement of the environmental issue. The resulting correlations, although imperfect, are felt to provide an indication of the approximate level of research directed at each environmental issue. 
The planned AES research projects have, in general, been classified according to the major energy forms being addressed by ERDA. Although the energy categories are relatively straightforward and selfexplanatory, it is felt that a more specific definition of four of them is needed here.

The Fossil-general category includes projects with essentially equal applicability to all fossil fuel energy forms. Heretofore, most of the se projects have been classified in AES program descriptions as coal, with some also classified as oil and gas, oil shale, or multi-technology. Their categorization as Fossil-general indicates more distinctly the broad applicability of this research to fossil fuel RD\&D.

A Multi-Technology category is designated to include all environmental research having broad applicability to several energy forms and without focus on a specific energy form.

The category of General Science contains research not directly related to energy technology development. A portion of this research is an outgrowth of ERDA assuming research responsibilities of the former Atomic Energy Commission.

In the Energy Reorganization Act of 1974 (Section 2b) it states:

"Establish an Energy Research and Development Administration to bring together and direct federal activities relating to research and development on the various sources of energy, to increase the efficiency and reliability in the use of energy, and to carry out the performance of other functions, including but not limited to the Atomic Energy Commission's military and production activities and its genral basic rese

The fourth category, Medical Applications of Nuclear Technology, is not related to environmental research, but is a continuation of research previously conducted by the former Atomic Energy Commission. 


\section{Tabulation of Results}

Tables of standardized format are presented in the following sections of the report for each major energy form. The first table in each section summarizes the planned environmental research associated with the specific energy form being discussed in that section. A subprogram level breakout is presented to show the level of activity for each major environmental discipline. Human Health and Biological studies have been combined into a single subprogram item. Recent transfers of projects between Human Health and Biological subprograms, resulting from AES program restructuring that occurred curing the course of this effort, has not permitted a clear separation of these two research areas for this reported effort.

Education and Training activities, totaling $\$ 6$ million for the planned FY 78 AES program, are addressed in the first table of each section. Since this funding is intended for educational activities and does not directly address the energy-related environmental issues identified in this report, it has not been included in the project-by-project correlation with the environmental issues in subsequent tables.

Tables of this report have classified planned research as either "focused" or "supportive" for a specific energy form. Each planned research project had been previously categorized by the AES divisional staff as supporting Coal, Oil and Gas, Oil Shale, Solar, Geothermal, Hydroelectric, Conservation, Fusion, Fission, Multi-technology, General Science, or Medical Applications of Nuclear Technology. For purposes of this report, projects were classified as "focused" on the energy form based upon this earlier categorization by the AES divisional staff urless a reclassification was indicated by the AES.staff when making the correlation of projects with the listed environmental issues. It was recognized, however, that a given project could be focused toward one energy form and also provide support to others as well. For example, many projects which were "focused" toward Coal also provided data applicable to Oil and Gas. Such a project would be listed both as "focused" in the Coal program and "supportive" in the Oil and Gas program. All projects 
categorized as Multi-technolagy were correlated with specific energy forms and given a "supportive" classification. Where a project was assigned as "supportive" to more than one energy form, the total funding of that project was in:luded in the supportive research table for each applicable energy form. Determination of the level of fractional support of each project to all environmental issues is a highly judgmental task and the compilation of such fractional assignments is complex. Such a determination was not attempted in this report.

The tabular listing of environmental is sues presented in this report has been organized into sublists for Integrated Systems Analysis, Physical and Technological, Health, and Environment. Integrated Systems Analysis includes issues assciated with environmental data integration, safety, energy materials transportation, social, cultural, and economic impacts. Physical and Technological includes radiological and chemical physics; physical ard chemical pollutant studies; and characterization, measurement, and monitoring. The Health listings :nclude biological issues. Environmental issue listings include atmospheric sciences; land/freshwater sciences; and marine sciences.

The second table in ecch "energy-specific" section of this report presents the correlation of the research summarized in the تirst table with the environmental issues identified for that energy form.

Note: The columns showing rumbers of projects and funding levels in these "second" tables are non-additive. Summation of these values is without meaning since 1) the environmental issues are not mutually exclusive, and 2) many research projects have been formulated to address multiple issues and, therefore, are correlated (relisted in each table) with all appropriate issues. 


\section{SECTION 2}

FUNDING SUMMARY

The planned FY 78 AES research program funding addressed in this zeport is summarized in Table 2-1. This table indicates the funding as sociated with each energy tectnology for the four AES Divisions. Although total and divisional funding shown here is consistent with AES program funding summaries presented elsewhere, the funding alignment with energy technologies shows some variation. These differences stem 1) from the inclusion of Fossil-general and Hydroelectric categories and 2) from the reassignment of energy technology categories for some projects by the AES technical staff members. These reassignments resulted from the close examination required to correlate each project with the numerous environmental issues.

A more detailed funding breakout, as well as a listing of the number of associated research projects, is presented for each energy technology in the first table of subsequent sections of this report. The funding summarized in Table 2-1 corresponds to the "focused" research presented in subsequent tables.

This report does not include the Reactor Safety program portion of the planned FY 78 AES budget. This activity, planned for a total FY 78 funding of $\$ 21.3$ million, is specifically oriented to the conduct of reactor safety. confirmatory research required by the Nuclear Regulatory Commission (NRC). The funding request is for completion and operational checkout of the Loss of Fluid Test Facility (LOFT). 
TABLE 2-1. FY 78 FUNDING SUMMARY

(Dollars in Thousands)

\begin{tabular}{|c|c|c|c|c|c|c|c|c|c|c|c|c|c|c|}
\hline AES Division & $\begin{array}{l}\text { Fossil- } \\
\text { General }\end{array}$ & Coal & $\begin{array}{l}\text { Oil \& } \\
\text { Gas } \\
\end{array}$ & $\begin{array}{c}\text { Oil } \\
\text { Shale } \\
\end{array}$ & Solar & $\begin{array}{c}\text { Geo- } \\
\text { thermal } \\
\end{array}$ & $\begin{array}{l}\text { Hydro- } \\
\text { electric }\end{array}$ & $\begin{array}{l}\text { Conser- } \\
\text { vation }\end{array}$ & Fission & Fusion & $\begin{array}{c}\text { Multi- } \\
\text { Technology }\end{array}$ & $\begin{array}{l}\text { General } \\
\text { Science }\end{array}$ & $\begin{array}{c}\text { Medical } \\
\text { Applications } \\
\end{array}$ & TOTAL \\
\hline Overview: and Assessment & 703 & 1,980 & 400 & 400 & 400 & 632 & 1,000 & 471 & 905 & 80 & 20,584 & - & - & 27,555 \\
\hline B:omedical and Environmental & 11,358 & 27,005 & 2,947 & 3,875 & 4,295 & 4,114 & 173 & 773 & 59,051 & 1,378 & 42,699 & 20,138 & 18,269 & 196,075 \\
\hline $\begin{array}{l}\text { Envircnental Control } \\
\text { Technology }\end{array}$ & - & 3,900 & 1,900 & 700 & 500 & 500 & - & 626 & 24,260 & - & 1,614 & - & - & 34,000 \\
\hline $\begin{array}{l}\text { Safety, Standards, and } \\
\text { Compliance }\end{array}$ & - & $\begin{array}{r}50 \\
. \quad \\
\end{array}$ & - & - & 100 & 125 & - & - & 2,725 & 100 & 6,470 & - & - & 9.570 \\
\hline TOTAL & $\underline{12,061}$ & 32,935 & 5,247 & 4,975 & 5,295 & $\underline{5,371}$ & 1,173 & $\underline{1,870}$ & 86,941 & 1,558 & 71,367 & 20,138 & 18,269 & 267,200 \\
\hline
\end{tabular}




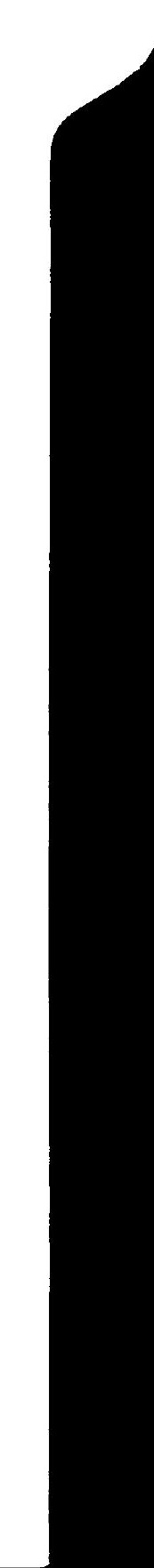


The category of "Fossil-general" includes research supportive of all fossil fuel energy technologies, but without focus on a specific fossil fuel. For example, research on the health or environmental impacts of $\mathrm{NO}_{x}, \mathrm{SO}_{\mathrm{x}}, \mathrm{CO}_{\mathrm{x}}$, and partic latates may often be classified as Fossil-general. Most research classified here as Fossil-general has, ir. previous AES program summaries, been classified as coal or multi-technology. Projects were included in this classification when they addressed issues in all fossil energy forms and when they had been previonsly assigned this Fossil-general category by the ERDA Laboratory and field office personnel. The Fcssil-general classification is used here to indicate more explicitly its wideapplicability to fossil energy RD\&D.

A listing of environmertal issues expressed in ERDA documents has not been included in this section. The compilation of environmertal is sues from the referenced sources found that issues were addressed in the context of a specific fossil fuel; and, therefore, these issues have been tabulated in the Coal, Oil and Gas, and Oil Shale sections of this report.

The planned level of FY 78 funding and number of Fossil-general research projects are summarized in Table 3-1. Environmental Control Technology and Safety, Standards, and Compliance activities have been oriented to specific fossil fuel issues, and, consequently, no fund ing is shown here. The funding is indicated as "focused" on Fossil-general research. In subsequent sections of the report, this research is correlated with statements of environmental issues and will appear whe rever applicable in the "supportive" research column of those tables. No research focused on other energy technologies is shown as "supportive" for Fossil-general since no en-ironmental issues were identified for Fossil-general to which other technology research could be correlated. 
TABLE 3-1. FOSSIL-GENERAL RESEARCH SUMMARY

Subprogram

Overview and Assessment

Health and Biological

\section{Environmental}

Physical and Technological

Education and Training

Environmental Control Technology

Safety, Standards, and Compliance TOTAL

\begin{tabular}{ll} 
Research & Projects \\
$\begin{array}{c}\text { Number of } \\
\text { Projects }\end{array}$ & Dollars in \\
\hline
\end{tabular}

7

703

40

6,871

16

3,077

7

1,410

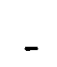

70

$\underline{\underline{12,061}}$ 


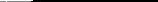


A summary of the planned FY 78 AES research categorized as "Coal" is presented in Table 4-1. The data indicate that over cne-half of the total funding for research focused on Coal addresses the timeurgent problems associated with health and environmental impacts of coal production and use. A substantial fraction of funding (12 percent) is focused on environmental control technolagies.

The funding listed as supportive of coal research represents program activities focused on other energy technologies that also have secondary applicability to environmental issues associated with coal. Only a fraction of the supportive research funding shown can be attributed to resolution of coal is sues.

The coal-related env:ronmental needs, concerns, and problems found in the referenced ERDA documents are listed in Table 4-2. This table also shows the correlation of all planned FY 78 coal research, both focuséd and supportive, with the environmental issues. As discussed previously the funding columns in Table 4-2 are non-additive since individual is sues are not mutually exclusive and projects may correlate with more than one issue, and, therefore, be entered more than once. Total funding levels are indicated, however, in Table 4-1. 
TABLE 4-1: COAL RESEARCH SUMMARY

\section{Subprogram}

Overview and Assessment

Health and Biological

Environmental

Physical and Technological

Education and Training

Environmental Control Technology

Safety, Standards, and Compliance

$$
\text { TOTAL }
$$

* These values are only fractionally applicable to this energy form.
Research

Projects

\begin{tabular}{|c|c|c|c|}
\hline \multicolumn{2}{|c|}{ Focused } & \multicolumn{2}{|c|}{ Supportive* } \\
\hline $\begin{array}{c}\text { Number of } \\
\text { Projects }\end{array}$ & $\begin{array}{l}\text { Dollars in } \\
\text { Thousands }\end{array}$ & $\begin{array}{c}\text { Number of } \\
\text { Projects }\end{array}$ & $\begin{array}{l}\text { Dollars in } \\
\text { Thousands }\end{array}$ \\
\hline 6 & 1,980 & 50 & 17,116 \\
\hline 56 & 10,021 & 70 & 12,903 \\
\hline 71 & 11,131 & 102 & 12,309 \\
\hline 1.3 & 3,138 & 46 & 6,473 \\
\hline 3 & 2,715 & - & - \\
\hline 12 & 3,900 & 11 & 1,614 \\
\hline 1 & 50 & 3 & 380 \\
\hline 162 & 32,935 & 282 & 50,795 \\
\hline
\end{tabular}


TABLE 4-2

MAJOR ISSUES - COAL

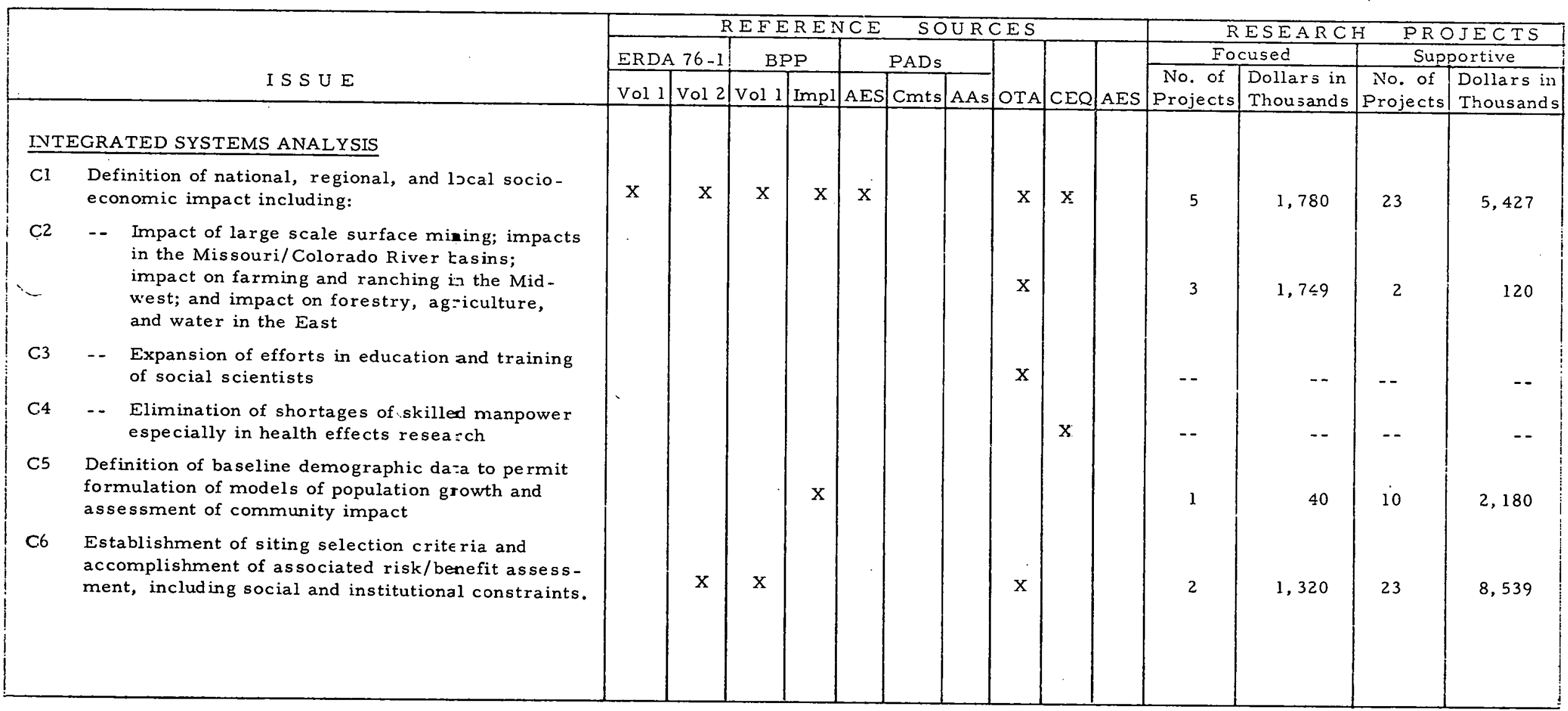


TABLE 4-2

MAJOR ISSUES - COAL

(continued)

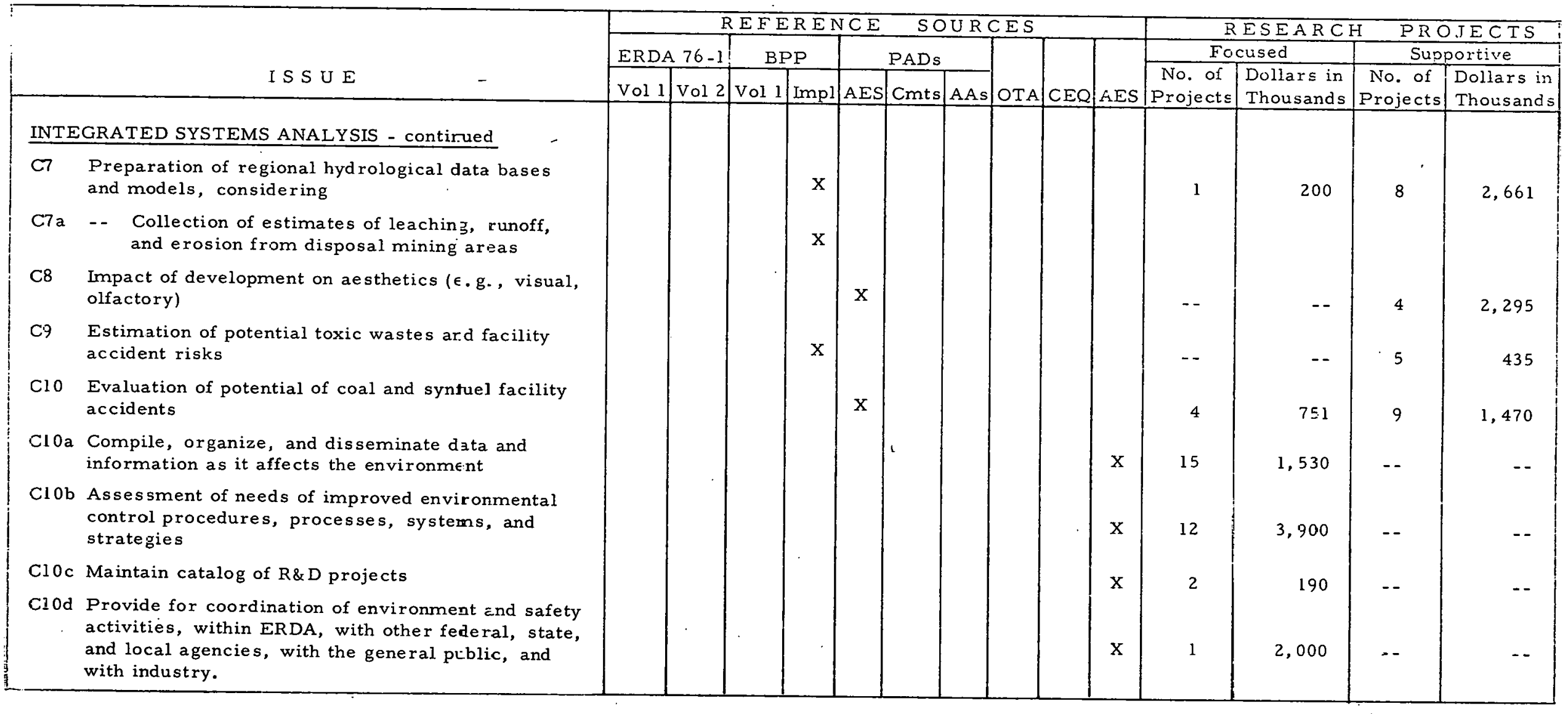


TABLE 4-2

MAJOR ISSUES - COAL

(continued)

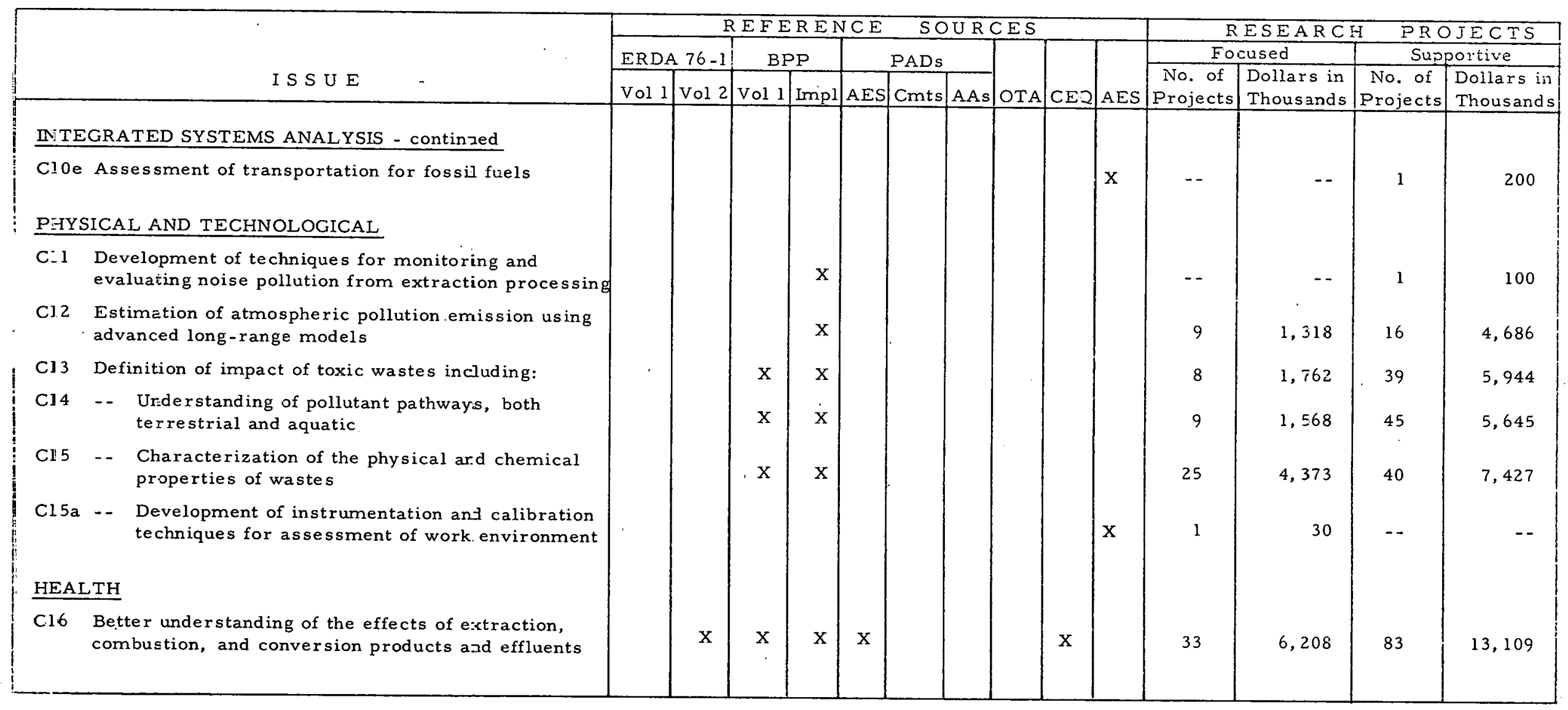


TABLE 4-2

MAJOR ISSUES - COAI

(continued)

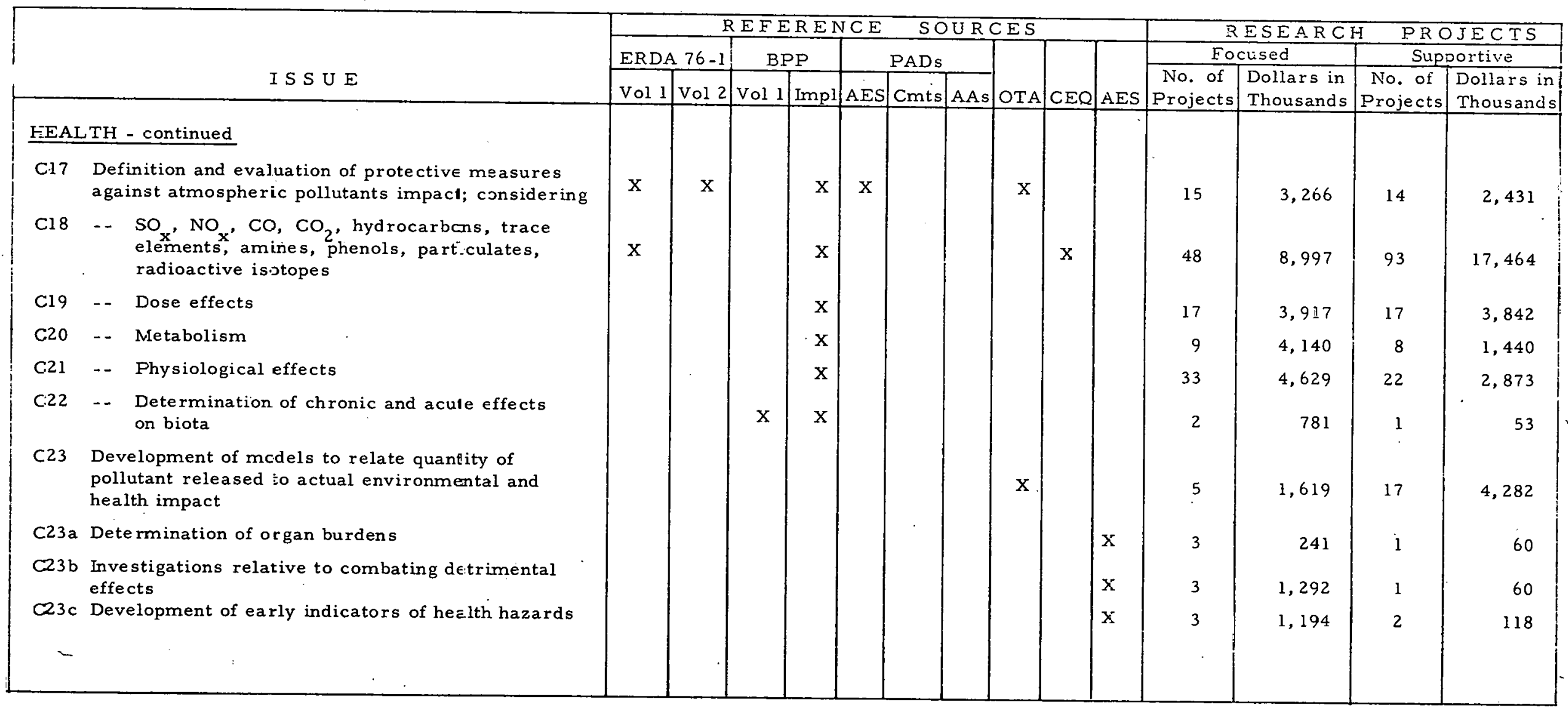


TABLE 4-2

MAJOR ISSUES - COAL

(continued)

\begin{tabular}{|c|c|c|c|c|c|c|c|c|c|c|c|c|c|c|c|}
\hline & \multirow[b]{3}{*}{ I S S U E } & \multicolumn{10}{|c|}{ REFERENCE } & \multirow{2}{*}{\multicolumn{2}{|c|}{\begin{tabular}{l|} 
RESEARCF \\
Focused
\end{tabular}}} & \multicolumn{2}{|c|}{ PROJECTS } \\
\hline & & \multicolumn{2}{|c|}{ ERDA $76-1$} & \multicolumn{2}{|c|}{ BPP } & \multicolumn{3}{|c|}{ PADs } & \multirow[b]{2}{*}{ OTA } & \multirow[b]{2}{*}{$C E Q$} & \multirow[b]{2}{*}{ AES } & & & \multicolumn{2}{|c|}{ Supportive } \\
\hline & & Vol 1 & Vol 2 & Vol l & Impl & AES & Cmts & AAs & & & & $\begin{array}{c}\text { No. of } \\
\text { Projects }\end{array}$ & $\begin{array}{l}\text { Dollars in } \\
\text { Thousands }\end{array}$ & \begin{tabular}{|c|} 
No. of \\
Projects \\
\end{tabular} & $\begin{array}{l}\text { Dollars in } \\
\text { Thousands }\end{array}$ \\
\hline \multicolumn{2}{|c|}{ ENVIRONMENT } & & & & & & & & & & & & & & \\
\hline $\mathrm{C} 24$ & $\begin{array}{l}\text { Evaluation of impact on water quality and avail- } \\
\text { ability considering: }\end{array}$ & $\mathrm{x}$ & $\mathrm{X}$ & $\mathrm{X}$ & $\mathrm{X}$ & $\mathrm{X}$ & & & $\mathrm{x}$ & s: & & 5 & 571 & 9 & 1,138 \\
\hline $\mathrm{C} 25$ & -- Leachates impact & & & & $\mathrm{X}$ & & & & & & & 5 & 1,622 & 2 & 117 \\
\hline $\mathrm{C} 26$ & $\begin{array}{l}\text { - Sulfates, ammonium, nitrates, acids, } \\
\text { trace metals, suspended solids }\end{array}$ & & & & $\mathrm{x}$ & & & & & & & 4 & 1,524 & 15 & 4,230 \\
\hline $\mathrm{C} 27$ & $\begin{array}{l}\text { - Fupture or spill from gasification/liquefaction } \\
\text { process }\end{array}$ & & & & $\mathrm{x}$ & & & & & & & 1 & 180 & 3 & 3,042 \\
\hline $\mathrm{C} 28$ & $\begin{array}{l}\text {-- Quantity of water needed to maintain quality } \\
\text { for aquatic biota }\end{array}$ & & & & $\mathrm{x}$ & & & & & & & 1 & 180 & 8 & 943 \\
\hline C.29 & $\begin{array}{l}\text { Identification and characterization of loxic wastes } \\
\text { disposal and treatment considering: }\end{array}$ & & $\mathrm{x}$ & & $\mathrm{x}$ & $\mathrm{X}$ & & & & & & 20 & 3,119 & 17 & 3,278 \\
\hline $\mathrm{C} 30$ & -- Ash, sulfur sludge, isotopes & & & & $\mathrm{X}$ & & & & & & & - & - & 7 & 3,143 \\
\hline C31 & -Waste heat management strategies & & & $\mathrm{x}$ & $\mathrm{x}$ & & & & & & & -- & - & 20 & 4,058 \\
\hline C32 & $\begin{array}{l}\text { - Acute and chronic effects on terrestrial } \\
\text { and aquatic species }\end{array}$ & & & $\mathrm{X}$ & $\mathrm{x}$ & & & & & & & 2 & 158 & 20 & 2,699 \\
\hline C33 & -- Hazardous biotransformation prociucts & & & & $\mathrm{x}$ & & & & & & & 3 & 346 & 9 & 1,416 \\
\hline
\end{tabular}


TABLE $4-2$

MAJOR ISSUES - COAL

(continued)

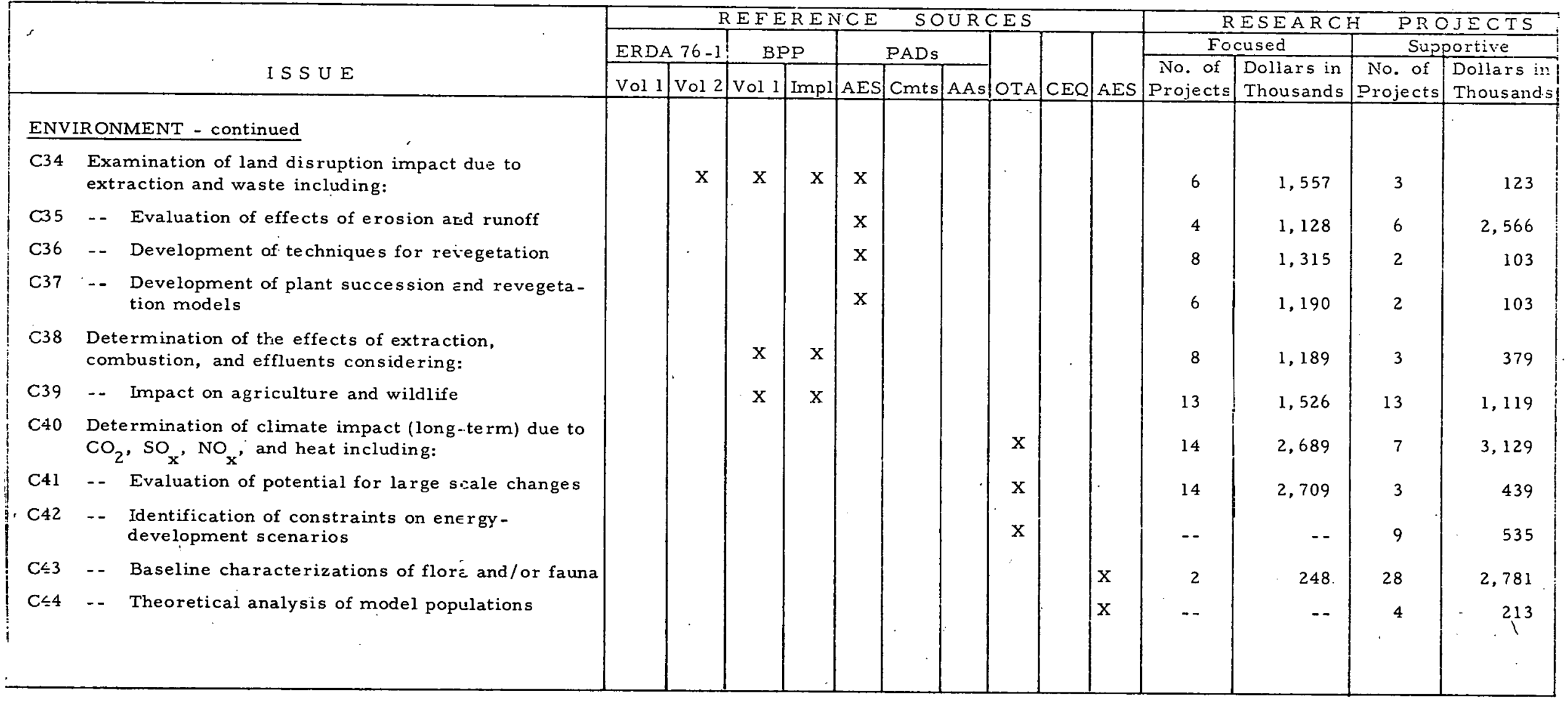




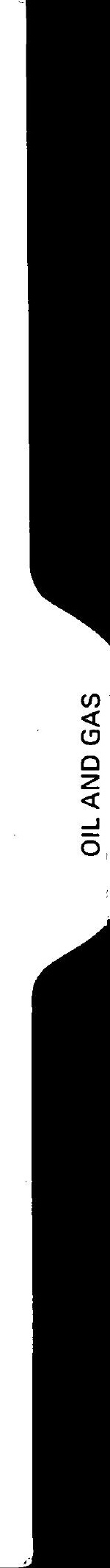




\section{SECTION 5 \\ OIL AND GAS}

A summary of the planned FY 78 AES research which has been categorized as "Oil and Gas" is presented in Table 5-1. Sinze most of the energy technology research in the field of oil and gas is directed toward the extraction of resources, most of the research is directed along environmental lines. Note that 90 percent of the "zocused" environmental research funds are applied in the areas of environmental effects and environmental control technology.

As mentioned in Section 4, Coal, the supportive research programs for Oil and Gas have primary applicability to other energy forms. Therefore, only a fraction of the funds shown for supportive research are applicable: to Oil and Gas issues.

The correlation of the Oil and Gas research to the environmental issues drawn from ERDA documentation is shown in Table 5-2. 
TABLE 5-1. OIL AND GAS RESEARCH SUMMAFY

Research

\begin{tabular}{|c|c|c|c|}
\hline \multicolumn{2}{|r|}{ Research } & \multicolumn{2}{|l|}{ Projects } \\
\hline \multicolumn{2}{|c|}{ Focused } & \multicolumn{2}{|c|}{ Supportive** } \\
\hline $\begin{array}{c}\text { Number of } \\
\text { Projects }\end{array}$ & $\begin{array}{l}\text { Dollars in } \\
\text { Thousands }\end{array}$ & $\begin{array}{c}\text { Number of } \\
\text { Projects }\end{array}$ & $\begin{array}{l}\text { Dollars in } \\
\text { Thousands }\end{array}$ \\
\hline
\end{tabular}

Overview and Assessment

1

Health and Biolc.gical

Environmental

Physical and Te=hnological

Education and Training

Environmental Control Technoiogy

Safety, Standards, and Compliance TOTAL

*These values are only fractional-y applicable to this energy form.
1

14

$-$

6

-

$\underline{\underline{22}}$
400

150

2,797

$$
-
$$

1,900

11
-
$\underline{\underline{5,247}}$

14,525

4,787

13,003

219

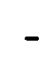

1,614

$\underline{-}$


TABLE 5-2

MAJOR ISSUES - OIL AND GAS

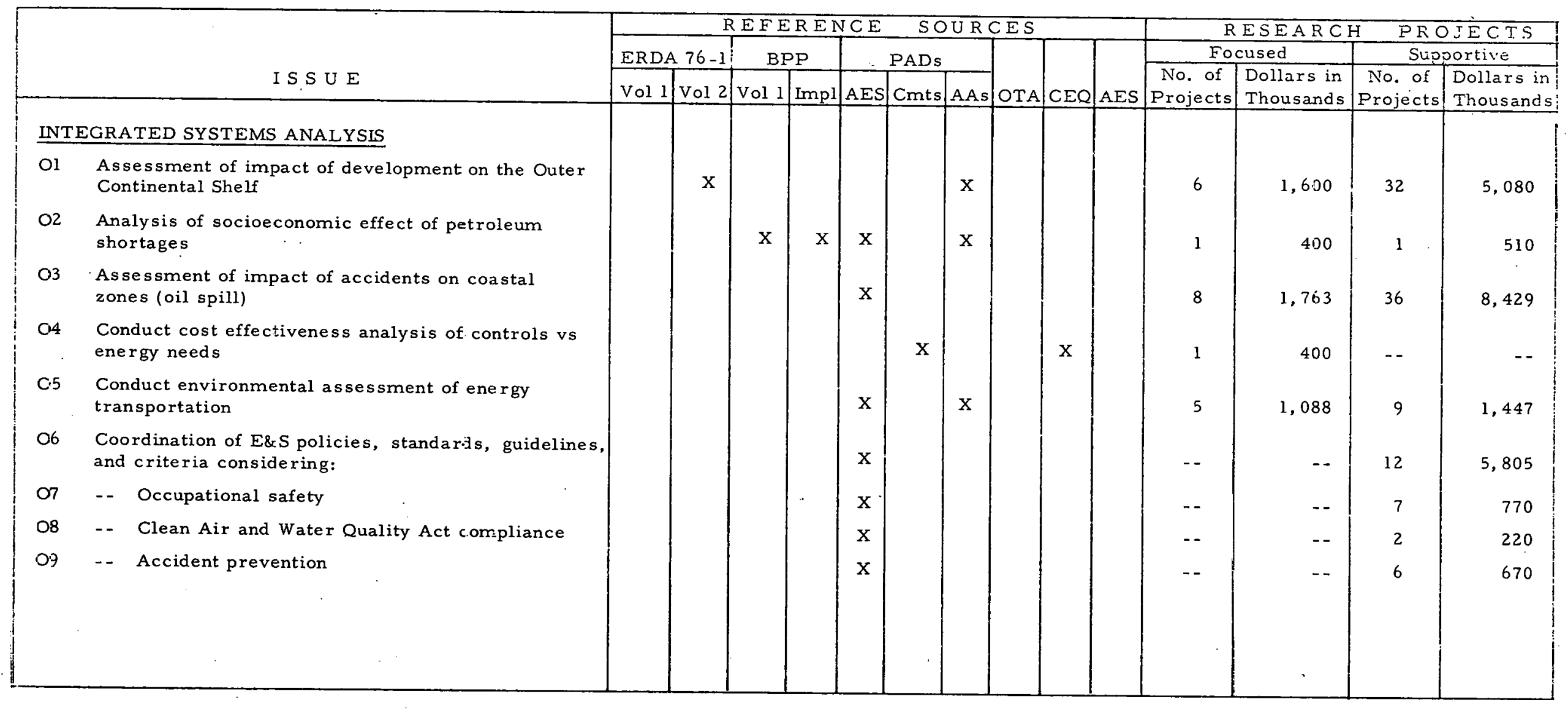


TABLE 5-2

MAJOR ISSUES - OIL AND GAS

(continued)

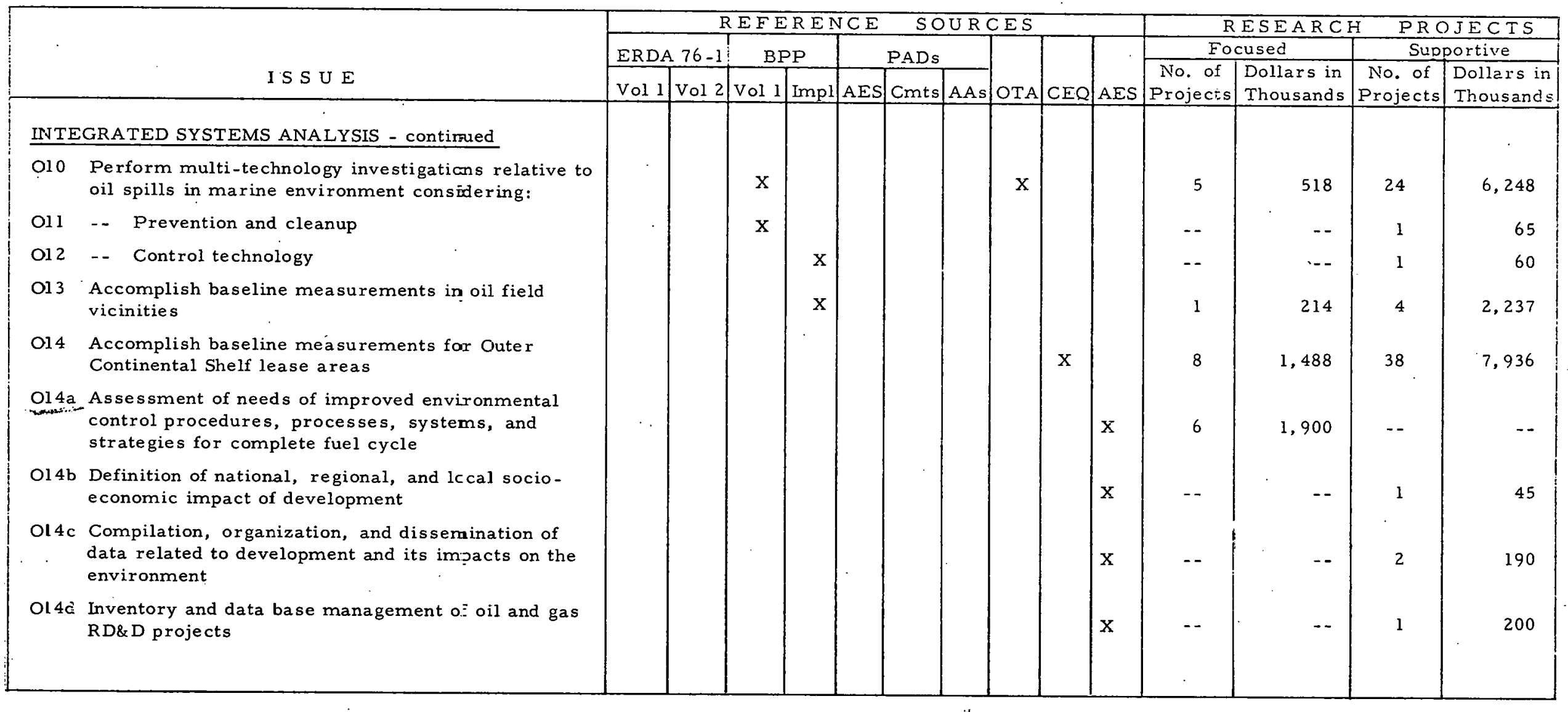


TABLE 5-2

MAJOR ISSUES - OIL AND GAS

(continued)

\begin{tabular}{|c|c|c|c|c|c|c|c|c|c|c|c|c|c|c|}
\hline \multirow[b]{3}{*}{ I S S U E } & \multicolumn{10}{|c|}{ REFERENCE } & \multicolumn{4}{|c|}{ PROJECTS } \\
\hline & \multicolumn{2}{|c|}{ ERDA. $76-1$} & \multicolumn{2}{|c|}{ BPP } & \multicolumn{3}{|c|}{ PADs } & \multirow[b]{2}{*}{ OTA } & \multirow[b]{2}{*}{ CEQ } & \multirow[b]{2}{*}{ AES } & \multicolumn{2}{|c|}{ Focused } & \multicolumn{2}{|c|}{ Supportive } \\
\hline & Vol 1 & Vol 2 & Vol 1 & Impl & AES & Cmts & AAs & & & & $\begin{array}{c}\text { No. of } \\
\text { Projects }\end{array}$ & $\begin{array}{l}\text { Dollars in } \\
\text { Thousands }\end{array}$ & \begin{tabular}{c|} 
No. of \\
Projects
\end{tabular} & $\begin{array}{l}\text { Dollars in } \\
\text { Thousands }\end{array}$ \\
\hline INTEGRATED SYSTENS ANALYSIS - continued & & & & & & & & & & & & & & \\
\hline $\begin{array}{l}\text { O14e Provide for coordination of E\&S activities within } \\
\text { ERDA; with other federal, state, anc local agencies; } \\
\text { with the public, and with industry }\end{array}$ & & & & & & & & & & $\mathrm{X}$ & - & -- & 1 & 2,000 \\
\hline $\begin{array}{l}\text { Ol.1f Monitor, review, and coordinate environmental } \\
\text { assessments and Environmental Impact Statements }\end{array}$ & & & & & & & & & & $\mathrm{x}$ & - - & - - & 1 & 3,000 \\
\hline PHYSICAL AND TECHROOLOGICAL & & & & & & & & & & & & & & \\
\hline O15: Development of oil spill characteriza:ion models & & & & $\mathrm{x}$ & $\mathrm{x}$ & & & & & & 5 & 518 & 9 & 1,074 \\
\hline $\begin{array}{l}\text { Ol6. Establishment of acceptable methods for transport } \\
\text { and disposal of brine }\end{array}$ & & $\mathrm{X}$ & & $\mathrm{x}$ & & & $\mathbf{x}$ & & & & -- & - & 1 & 125 \\
\hline $\begin{array}{l}\text { O17 Characterization cf transport and disposal of } \\
\text { gaseous emissions }\end{array}$ & & - & & $\mathrm{X}$ & $\mathrm{x}$ & & & & & & -- & -- & 27 & 4,991 \\
\hline FEALTH & & & & & & & & & & & & & & \\
\hline $\begin{array}{l}\text { C18 Determination of effects of gaseous ernissions on } \\
\text { oil and gas employ?es including: }\end{array}$ & $\mathrm{X}$ & & & $\mathrm{X}$ & & & & & & & -- & -- & 13 & 2,106 \\
\hline Ol9 -- Carcinogenic potential of hydroca:-bons & & & & $\mathrm{x}$ & & & & & & & -- & -- & 30 & 6,029 \\
\hline 020. Definition of health effects on refinery workers & & & $\mathrm{x}$ & & & & & & & & -- & - - & 5 & 935 \\
\hline
\end{tabular}


TABLE 5-2

MAJOR ISSUES - OIL AND GAS

(continued)

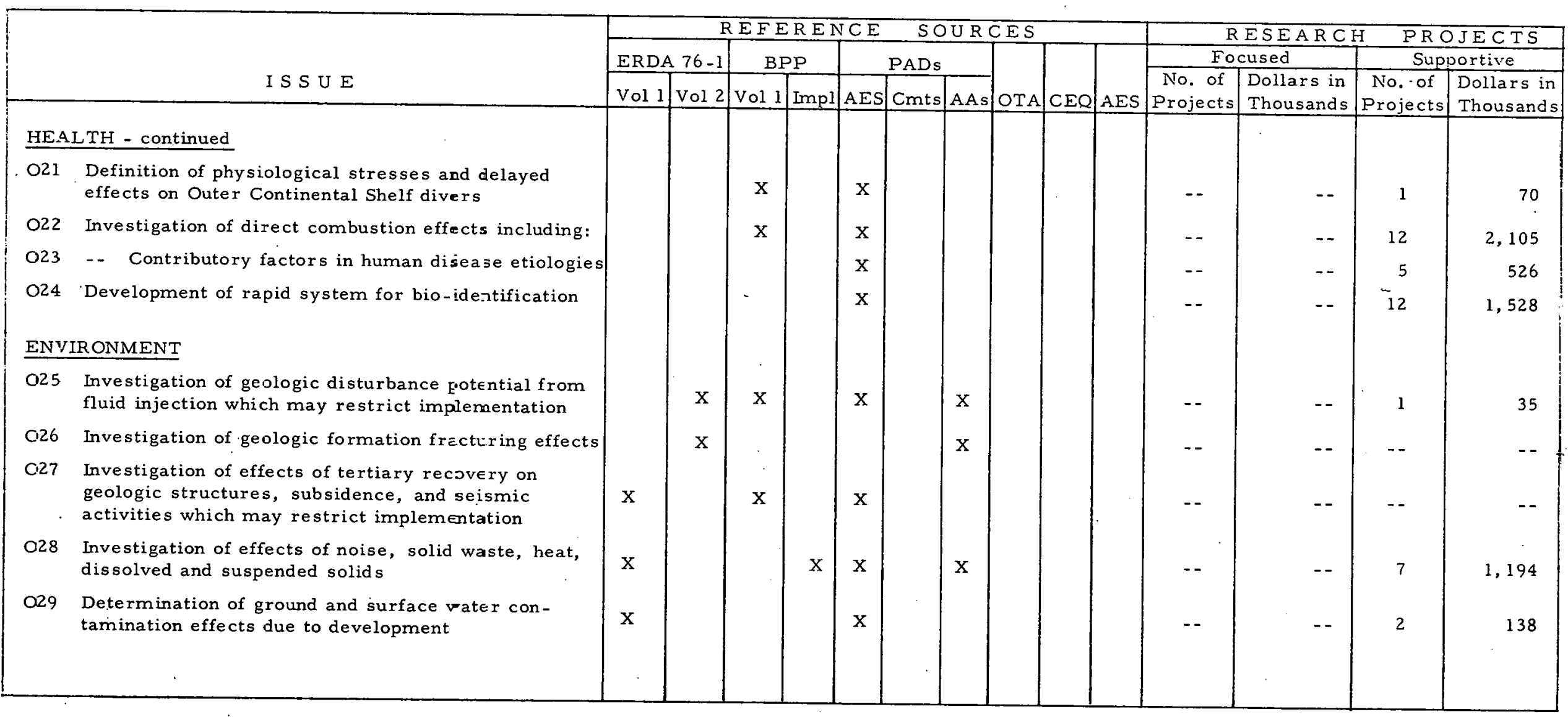


TABLE 5-2

MAJOR ISSUES - OIL AND GAS

(continued)

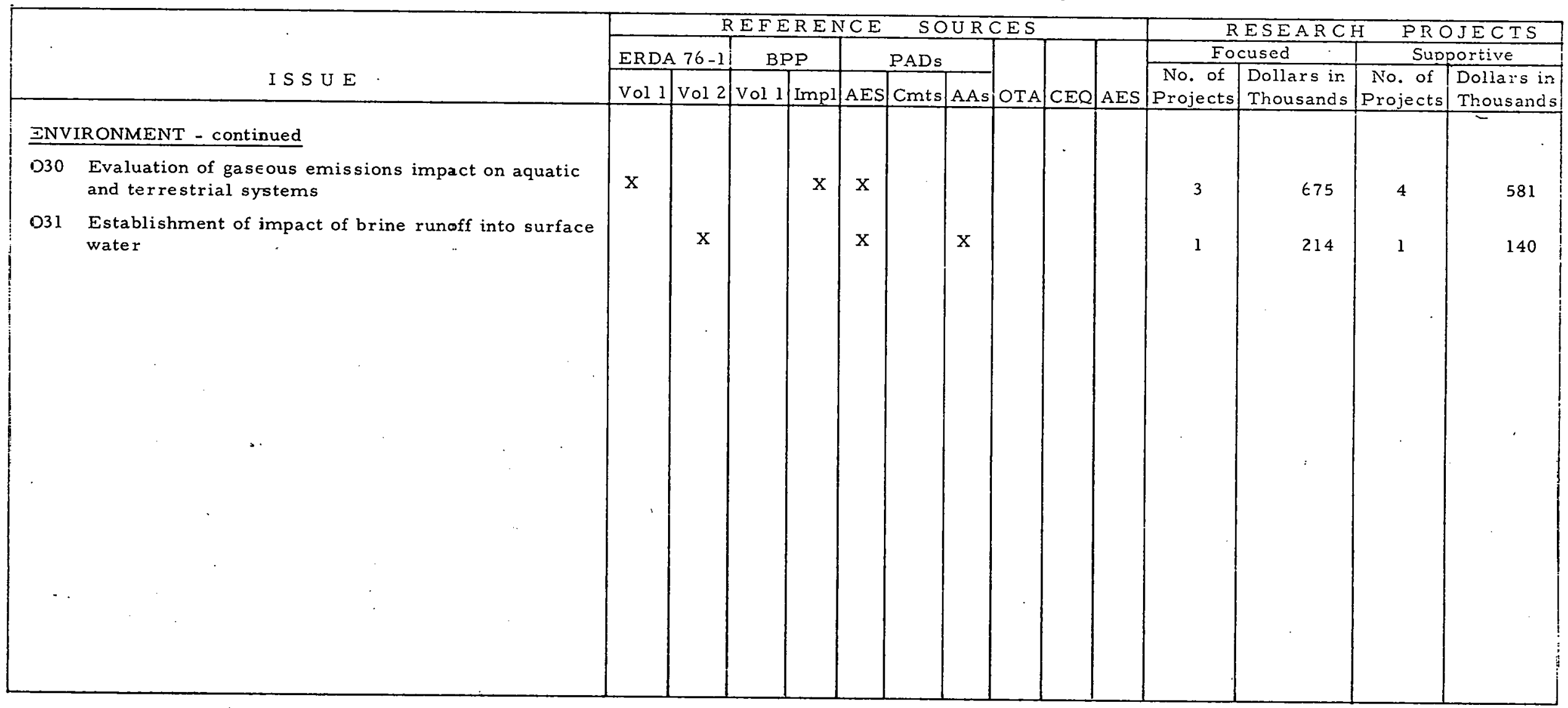




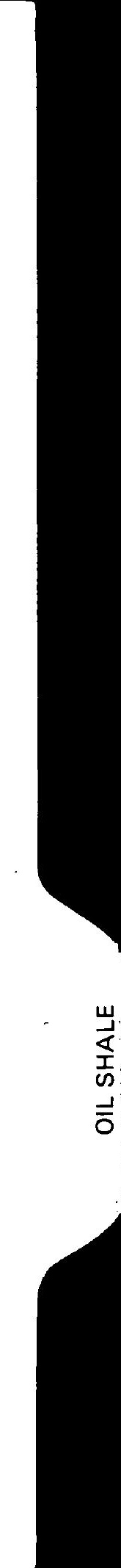




\section{SECTION 6 \\ OIL SHA LE}

A summary of the planned FY 78 AES research which has been categorized as "Oil Shale" is presented in Table 6-1. Basically, the research programs in the FY 78 program are directed toward the health and environmental efiects from the extraction/processing phases of the oil shale energy cycle. The large level of supportive research comes primarily from the applicability of Fossil-general and Coal research activities to Oil Shale issues. Only a fraction of the supportive research funcing shown can be related directly to Oil Shale research needs.

The correlation of this Oil Shale research with expressed environmental is sues is shown in Table 6-2. 
TABLE 6-1. OIL SHALE RESEARCH SUMMARY

Research

\begin{tabular}{|c|c|}
\hline \multicolumn{2}{|c|}{ Focused } \\
\hline $\begin{array}{c}\text { Number of } \\
\text { Projects } \\
\end{array}$ & $\begin{array}{l}\text { Dollars in } \\
\text { Thousand } \\
\end{array}$ \\
\hline 1 & 400 \\
\hline 9 & 1,336 \\
\hline 9 & 2,059 \\
\hline 3 & 480 \\
\hline - & - \\
\hline 3 & 700 \\
\hline$=$ & - \\
\hline$\underline{\underline{26}}$ & $\underline{\underline{4,975}}$ \\
\hline
\end{tabular}

Projects

Supportive*

\begin{tabular}{cc}
$\begin{array}{c}\text { Number of } \\
\text { Projects }\end{array}$ & $\begin{array}{c}\text { Dollars in } \\
\text { Thousands }\end{array}$ \\
\hline
\end{tabular}

\section{Subprogram}

Overview and Assessment

Health and Biological

Environmental

Physical and Technological

Education and Training

Environmental Control Technology

Safety, Standards, and Compli.ance

TOTAL

*These values are only fractionally applicable to this energy form.
34

77

18

46

13,975

11,992

2,308

6,473

1,614

11

$\frac{-}{186}$

36,362 
TABLE 6-2

MAJOR ISSUES - OIL SHALE

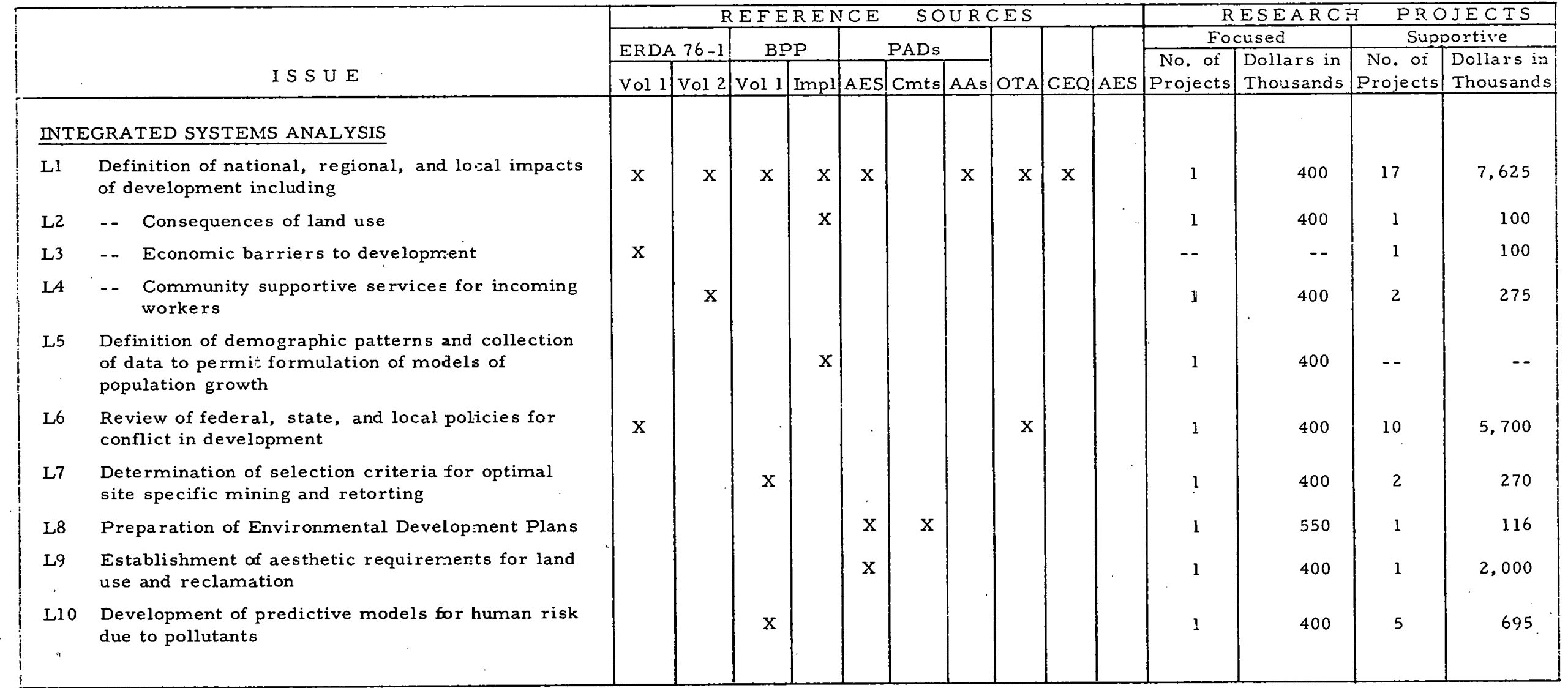


TABLE 6-2

MAJOR ISSUES - OIL SHALE

(continued)

\begin{tabular}{|c|c|c|c|c|c|c|c|c|c|c|c|c|c|c|c|}
\hline \multirow{3}{*}{\multicolumn{2}{|c|}{ I S S U E }} & \multicolumn{10}{|c|}{ REFERENCE } & \multirow{2}{*}{\multicolumn{2}{|c|}{ 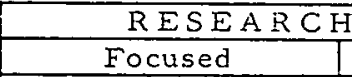 }} & \multirow{2}{*}{\multicolumn{2}{|c|}{$\begin{array}{l}\text { PROJECTS } \\
\text { Supportive }\end{array}$}} \\
\hline & & \multicolumn{2}{|c|}{ ERDA $76-1$} & \multicolumn{2}{|c|}{$\mathrm{BPP}$} & \multicolumn{3}{|c|}{ PADs } & \multirow[b]{2}{*}{ OTA } & \multirow[b]{2}{*}{ CEQ } & \multirow[b]{2}{*}{ AES } & & & & \\
\hline & & Vol 1 & Vol 2 & Vol l & Impl & AES & Cmts & AAs & & & & \begin{tabular}{|c|} 
No. of \\
Projects \\
\end{tabular} & $\begin{array}{l}\text { Dollars in } \\
\text { Thousands } \\
\end{array}$ & $\begin{array}{c}\text { No. of } \\
\text { Projects }\end{array}$ & $\begin{array}{l}\text { Dollars in } \\
\text { Thousand }\end{array}$ \\
\hline INTE & CGRATED SYSTEMS ANALYSIS - ccntinued & & & & & & & & & & & & & & \\
\hline Ll 0a & $\begin{array}{l}\text { Compilation, organization, and dissemination of } \\
\text { data and information relative to developmental } \\
\text { effects on the environment }\end{array}$ & & & & & & & & & & $\mathrm{x}$ & -- & -- & 14 & 1,485 \\
\hline $\mathrm{LlOb}$ & $\begin{array}{l}\text { Inventory and data base managemezt of oil shale } \\
\text { RD\& D projects }\end{array}$ & & & & & & & & & & $\mathrm{x}$ & -- & -- & 2 & 190 \\
\hline $\mathrm{Ll} 10 \mathrm{C}$ & $\begin{array}{l}\text { Coordination of E\&S activities with activities within } \\
\text { ERDA; with other federal, state, a.d local agencies; } \\
\text { with the public; and with industry }\end{array}$ & & & & & & & & & & $\mathrm{x}$ & -- & -- & 1 & 2,000 \\
\hline L10d & $\begin{array}{l}\text { Monitor, review, and coordinate ervironmental } \\
\text { assessments and Environmental Impact Statements }\end{array}$ & & & & & & & & & & $\mathrm{x}$ & -- & $\div-$ & 1 & 3,000 \\
\hline $\mathrm{L} 10 \mathrm{e}$ & $\begin{array}{l}\text { Assessment of needs of improved environmental } \\
\text { control procedures, processes, systems, and } \\
\text { strategies for complete fuel cycle }\end{array}$ & & & & & & & & & & $\mathrm{x}$ & 4 & 700 & -- & -- \\
\hline PHYS & SICAL AND TECHNOLOGICAL & & & & & & & & & & & & & & \\
\hline L11 & $\begin{array}{l}\text { Obtain qualitative and quantitative data on potential } \\
\text { toxicants }\end{array}$ & & & & $\mathrm{x}$ & & & & & & & 6 & 1,330 & 18 & 4,321 \\
\hline L12 & Accomplishment of water quality measurements & $\mathrm{X}$ & $\mathrm{X}$ & & $\mathrm{X}$ & & & & & & & 2 & 494 & 4 & 430 \\
\hline L13 & $\begin{array}{l}\text { Characterization of atmospheric emissions from } \\
\text { demonstration plants }\end{array}$ & & & $\mathrm{x}$ & $\mathrm{X}$ & & & & & & & 2 & 830 & 8 & 3,142 \\
\hline
\end{tabular}


TABLE 6-2

MAJOR ISSUES - OIL SHALE

(continued)

\begin{tabular}{|c|c|c|c|c|c|c|c|c|c|c|c|c|c|c|c|}
\hline \multirow{3}{*}{\multicolumn{2}{|c|}{ I S S U E }} & \multicolumn{10}{|c|}{ REFERENCE } & \multicolumn{4}{|c|}{ RESEARCH } \\
\hline & & \multicolumn{2}{|c|}{ ERDA $76-1$} & \multicolumn{2}{|c|}{$\mathrm{BPP}$} & \multicolumn{3}{|c|}{ PADs } & \multirow[b]{2}{*}{ OTA } & \multirow[b]{2}{*}{ CEQ } & \multirow[b]{2}{*}{ AES } & \multicolumn{2}{|c|}{ Focused } & \multicolumn{2}{|c|}{ Supportive } \\
\hline & & Vol 1 & Vol 2 & Vol 1 & Impl & $A E S$ & Crnts & A.As & & & & $\begin{array}{c}\text { No. of } \\
\text { Projects }\end{array}$ & $\begin{array}{l}\text { Dollars in } \\
\text { Thousands }\end{array}$ & $\begin{array}{l}\text { No. oi } \\
\text { Projects }\end{array}$ & $\begin{array}{l}\text { Dollars in } \\
\text { Thousands }\end{array}$ \\
\hline \multicolumn{2}{|c|}{ HEALTH } & & & & & & & & & & & & & & \\
\hline Ll 4 & Definition of effects from extractior and processing & $\mathrm{X}$ & $\mathrm{x}$ & $\mathrm{x}$ & $\mathrm{X}$ & $\mathrm{X}$ & & $\mathrm{x}$ & $\mathrm{x}$ & $\mathrm{x}$ & & 9 & 1,376 & 26 & 4,251 \\
\hline Ll 5 & $\begin{array}{l}\text { Consideration of hazardous organic compounds } \\
\text { (polyaromatic hydrocarbons and trace elements) }\end{array}$ & $\mathbf{x}$ & $\mathrm{x}$ & & $\mathrm{X}$ & & & & & & & 8 & 1,176 & 49 & 8,624 \\
\hline L16 & $\begin{array}{l}\text {-- Consideration of occupational hazards (poly- } \\
\text { aromatics, :norganic, and trace elements) }\end{array}$ & & & $\mathrm{x}$ & & & & & & & & 8 & 1,276 & 19 & 4,143 \\
\hline L17 & $\begin{array}{l}\text {-- Determination of mutagenicity of organic } \\
\text { compounds }\end{array}$ & & & $\mathrm{x}$ & $\mathrm{X}$ & & & & & & & 1 & 68 & 14 & 6,874 \\
\hline L1 8 & $\begin{array}{l}\text { Definition of efferts of direct combustion of oil } \\
\text { shale required }\end{array}$ & & & $\mathrm{x}$ & & & & & & & & 7 & 1,208 & 12 & 2,798 \\
\hline Ll9 & $\begin{array}{l}\text {-- Consideration of population expcsed to sulfates, } \\
\text { nitrates, } \mathrm{NO}_{\mathrm{x}} \text {, organic compounds, oxidants, } \\
\text { and trace elements }\end{array}$ & & & $\mathrm{X}$ & & & & & & & & 7 & 988 & 16 & 3,025 \\
\hline $\mathrm{L} 20$ & $\begin{array}{l}\text {-- Development of early indicators of stress and } \\
\text { damage }\end{array}$ & & & $\mathrm{x}$ & & & & & & & & 6 & 888 & 7 & 885 \\
\hline L21 & -- Identification of hazardous agents & & & $\mathrm{x}$ & & & & & & & & 8 & 1,323 & 16 & 2,704 \\
\hline$=22$ & $\begin{array}{l}\text { Understanding of physiological processes and } \\
\text { responses }\end{array}$ & & & $\mathbf{X}$ & & & & & & & & 8 & 1,056 & 25 & 3,550 \\
\hline $\mathbf{L} 23$ & -- Conduct chemical and epidemiological studies & & & $\mathbf{X}$ & & & & & & & & 1 & 335 & 3 & 325 \\
\hline
\end{tabular}


TABLE 6-2

MAJOR ISSUES - OIL SHALE

(continued)

\begin{tabular}{|c|c|c|c|c|c|c|c|c|c|c|c|c|c|c|c|}
\hline \multirow{3}{*}{\multicolumn{2}{|c|}{ I S S U E }} & \multicolumn{10}{|c|}{ REFERENCE } & \multirow{2}{*}{\multicolumn{2}{|c|}{$\begin{array}{l}\text { RESEARCH } \\
\text { Focused }\end{array}$}} & \multirow{2}{*}{\multicolumn{2}{|c|}{$\frac{\text { PROJECTS }}{\text { Supportive }}$}} \\
\hline & & \multicolumn{2}{|c|}{ ERDA $76-1$} & \multicolumn{2}{|c|}{ BPP } & \multicolumn{3}{|c|}{ PADs } & \multirow[b]{2}{*}{ OTA } & \multirow[b]{2}{*}{ CEQ } & \multirow[b]{2}{*}{ AES } & & & & \\
\hline & & Vol 1 & Vol 2 & Vol 1 & Impl & AES & Cmts & AAs & & & & $\begin{array}{c}\text { No. of } \\
\text { Projects }\end{array}$ & $\begin{array}{l}\text { Dollars in } \\
\text { Thousands }\end{array}$ & $\begin{array}{c}\text { No. of } \\
\text { Projects }\end{array}$ & $\begin{array}{l}\text { Dollars in } \\
\text { Thousands }\end{array}$ \\
\hline L24 & Definition of degradation of limited wate= resources & $\mathrm{X}$ & $\mathrm{x}$ & $\mathrm{X}$ & $\mathrm{x}$ & $\mathrm{X}$ & & $\mathrm{x}$ & $\mathrm{x}$ & $x$ & & 4 & 910 & 2 & 210 \\
\hline L25 & $\begin{array}{l}\text { Evaluation of impact of diversion of water } \\
\text { resources from agriculture }\end{array}$ & & & & $\mathrm{x}$ & & & & & & & 1 & 100 & -- & \\
\hline L26 & $\begin{array}{l}\text {-- Evaluation of impact of increased salinity of } \\
\text { water }\end{array}$ & & & & $\mathrm{x}$ & & & & & & & 2 & 160 & -- & -- \\
\hline L27 & $\begin{array}{l}\text {-- Evaluation of impact of quality of aquifers and } \\
\text { surface waters }\end{array}$ & $\mathrm{X}$ & & $\mathrm{x}$ & & & & & & & & 2 & 300 & -- & -- \\
\hline $\mathrm{L} 28$ & $\begin{array}{l}\text { - Investigation c.f recovery and reçcling of } \\
\text { waste water }\end{array}$ & $\mathrm{x}$ & $\mathrm{x}$ & & & & & & & & & 1 & 100 & -- & -- \\
\hline 129 & $\begin{array}{l}\text { Determination of impact of high qualit } \text { air } \\
\text { degradation due to pollutants, including: }\end{array}$ & $\mathrm{X}$ & & $\mathrm{x}$ & $\mathrm{x}$ & $\mathrm{x}$ & & $\mathrm{X}$ & $\mathrm{X}$ & $\mathrm{x}$ & & 3 & 1,060 & 3 & 2,354 \\
\hline L31 & $\begin{array}{l}\text { Definition of land dis ruption due to extraction and } \\
\text { processing, including: }\end{array}$ & $\mathrm{X}$ & $\mathrm{x}$ & $\mathrm{x}$ & $x$ & & $\mathrm{X}$ & & $\mathrm{x}$ & $\mathrm{X}$ & & 3 & 850 & 1 & 2,000 \\
\hline L32 & -- Consideration of disposal of spent shale & $\mathrm{x}$ & $\mathrm{x}$ & & $\mathrm{X}$ & & & & $\mathrm{x}$ & & & 2 & 560 & 1 & 81 \\
\hline L33 & -- Research on revegetation & $\mathrm{x}$ & & $\mathrm{X}$ & & & & & & & & 1 & 400 & - & - \\
\hline I34 & $\therefore$ Consideration of land subsidence impact & $\mathrm{X}$ & & & & & & & & & & -- & -- & - & - \\
\hline
\end{tabular}


TABLE 6-2

MAJOR ISSUES - OIL SHALE

(continued)

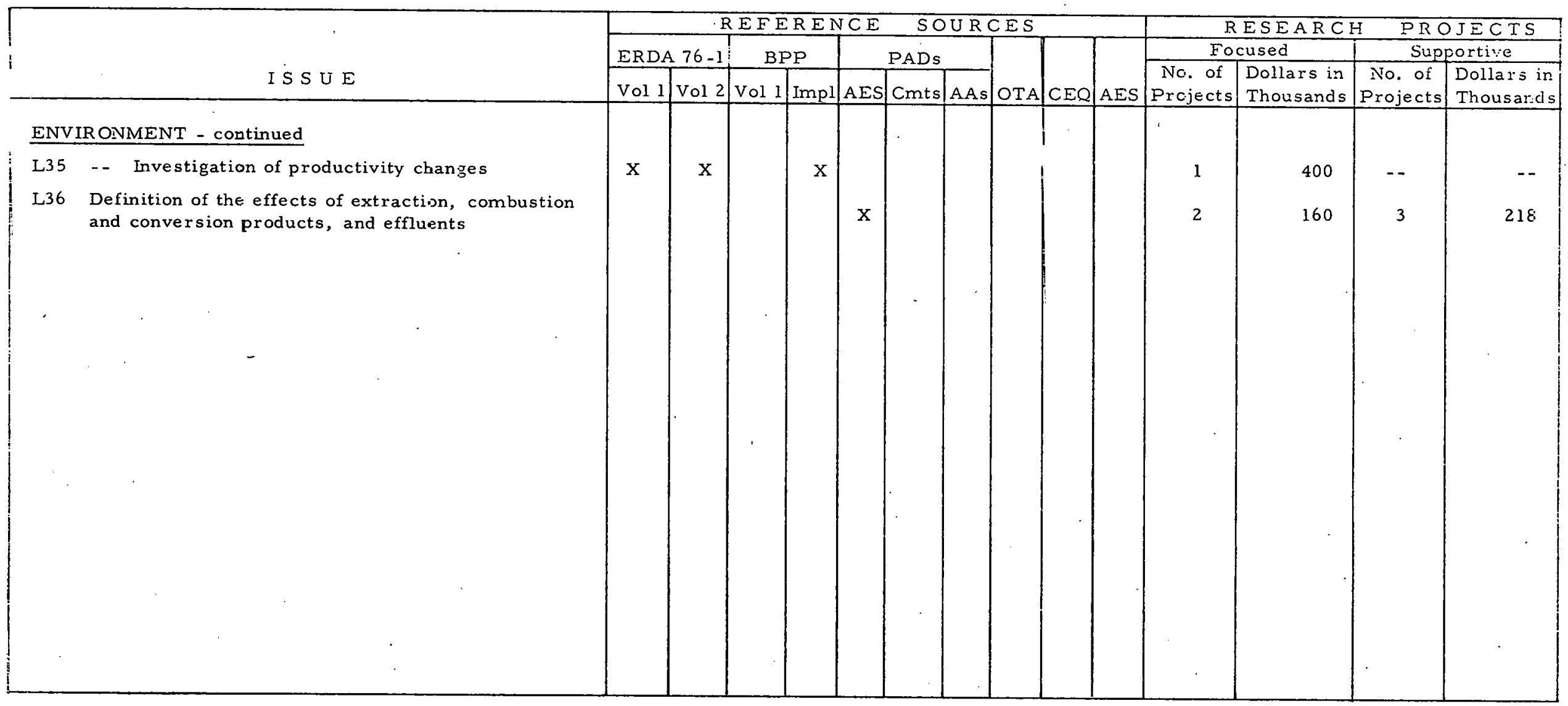




\section{SECTION 7}

SOLAR

A summary of the planned FY 78 AES research which has been categorized as "Solar" is presented in Table 7-1. It is evident that the major thrust of the program is in the Health and Biological area where the emphasis is on photosyntretic and biomass processes. A high level of supportive research for this technology from planned Overview and Assessment activities reflects the broad applicability of integrated assessments of environmental impacts, and social, cultural, and economic studies to be conducted on local, regional, and national levels.

The correlation of the Solar research to the major environmental issues drawn from ERDA documentation is presented in Table $7-2$. 
IABLE 7-1. SOLAR RESEARCH SUMMARY

\section{Subprogram}

Overview and Assessment

Health and Biological

Environmental

Physical and Technological

Education and Training

Environmental Control Technclogy

Safety, Standards, and Compliarce IOTAL

*These values are only fractionally applicable to this energy form.
Research

Projects

\begin{tabular}{|c|c|c|c|}
\hline \multicolumn{2}{|c|}{ Focused } & \multicolumn{2}{|c|}{ Supportive: } \\
\hline $\begin{array}{c}\text { Number of } \\
\text { Projects } \\
\end{array}$ & $\begin{array}{l}\text { Dollars in } \\
\text { Thousands }\end{array}$ & $\begin{array}{c}\text { Number of } \\
\text { Projects }\end{array}$ & $\begin{array}{l}\text { Dollars it } \\
\text { Thousand }\end{array}$ \\
\hline 1 & 400 & 36 & 15,005 \\
\hline 37 & 3,324 & 24 & 3,203 \\
\hline 4 & 971 & 47 & 7,459 \\
\hline - & - & 1 & 154 \\
\hline- & - & - & - \\
\hline 1 & 500 & - & - \\
\hline 1 & 100 & - & - \\
\hline$\underline{\underline{44}}$ & $\underline{5,295}$ & 108 & 25,821 \\
\hline
\end{tabular}


TABLE 7-2

MAJOR ISSUES - SOLAR

\begin{tabular}{|c|c|c|c|c|c|c|c|c|c|c|c|c|c|c|c|}
\hline \multirow{3}{*}{\multicolumn{2}{|c|}{ I S S U E }} & \multicolumn{10}{|c|}{ REFERENCE } & \multirow{2}{*}{\multicolumn{2}{|c|}{\begin{tabular}{|l|} 
RESEARCH \\
Focused
\end{tabular}}} & \multirow{2}{*}{\multicolumn{2}{|c|}{$\begin{array}{l}\text { PROJECTS } \\
\text { Supportive }\end{array}$}} \\
\hline & & \multicolumn{2}{|c|}{ ERDA $76-1$} & \multicolumn{2}{|c|}{ BPP } & \multicolumn{3}{|c|}{ PADs } & \multirow[b]{2}{*}{ OTA } & \multirow[b]{2}{*}{$C E O$} & \multirow[b]{2}{*}{ AES } & & & & \\
\hline & & Vol 1 & Vol 2 & Vol 1 & Impl & AES & Cmts & AAs & & & & $\begin{array}{c}\text { No. of } \\
\text { Projects }\end{array}$ & $\begin{array}{l}\text { Dollars in } \\
\text { Thousands }\end{array}$ & $\begin{array}{c}\text { No. of } \\
\text { Projects }\end{array}$ & $\begin{array}{l}\text { Dollars in } \\
\text { Thousands }\end{array}$ \\
\hline \multicolumn{16}{|c|}{ INTTEGRATED SYSTEMS ANALYSIS } \\
\hline S: & $\begin{array}{l}\text { Definition of national, regional, and lecal socio- } \\
\text { economic impact ir-cluding: }\end{array}$ & $\mathrm{X}$ & $\mathrm{X}$ & $\mathrm{X}$ & $\mathrm{X}$ & $\mathrm{X}$ & $\mathrm{X}$ & $\mathrm{X}$ & $\mathrm{X}$ & ' $\mathrm{x}$ & & 1 & 400 & 11 & 2,280 \\
\hline S2 & $\begin{array}{l}\text {-- Determination of relative heating and cooling } \\
\text { investment }\end{array}$ & $\mathrm{X}$ & $\mathrm{X}$ & & $\mathrm{x}$ & & & & & & & -- & -- & -- & -- \\
\hline S3 & -- Population trends to large facilities & & $\mathrm{x}$ & & & & & & & & & - & -- & -- & -- \\
\hline S4 & -- Radio and TV interference & & $\mathrm{x}$ & & $\mathrm{x}$ & & & & & & & -- & - - & - & -. \\
\hline S5 & -. Large land requirements & & $\mathrm{X}$ & & $\mathrm{X}$ & & & & & & & -- & -- & -- & - - \\
\hline S6 & $\begin{array}{l}\text { Implementation of program for end user education } \\
\text { and information dissemination }\end{array}$ & $\mathrm{X}$ & & & & & & $\mathrm{X}$ & & & & 1 & 100 & 16 & 1,935 \\
\hline Si & $\begin{array}{l}\text { Implementation of planning for land use and } \\
\text { as sociated regulations }\end{array}$ & $\mathrm{X}$ & $\mathrm{X}$ & $\mathrm{x}$ & & & & $\mathrm{x}$ & & $\mathrm{X}$ & & 1 & 400 & 1 & 2,000 \\
\hline $\mathrm{S} \&$ & Definition of air, sian, and sea rights & $\mathrm{x}$ & $\mathbf{x}$ & & & & & & & & & -- & -- & -- & -- \\
\hline S: & $\begin{array}{l}\text { Evaluation of impact of building codes anci } \\
\text { measurement standards }\end{array}$ & $\mathrm{x}$ & $\mathrm{x}$ & & & & & & $\mathrm{x}$ & $\mathrm{x}$ & & -- & -- & 10 & 5,700 \\
\hline Slo & Ensure availability of pertinent data to industry & & $\mathrm{x}$ & & & & & & $\mathrm{X}$ & $\mathrm{x}$ & & 1 & 100 & 2 & 450 \\
\hline Sll & Definition of impact of development on aesthetics & $\mathrm{X}$ & $\mathrm{x}$ & & $\mathrm{X}$ & & & & & $\mathrm{X}$ & & 1 & 400 & 1 & 254 \\
\hline $\mathrm{S} 12$ & $\begin{array}{l}\text { Assessment of impact of commercialism upon } \\
\text { development }\end{array}$ & $\mathrm{x}$ & $\mathrm{x}$ & & & & & $\mathrm{X}$ & $\mathrm{x}$ & & & 1 & 400 & - & -- \\
\hline
\end{tabular}


TABLE 7-2

MAJOR ISSUES - SOLAR

(continued)

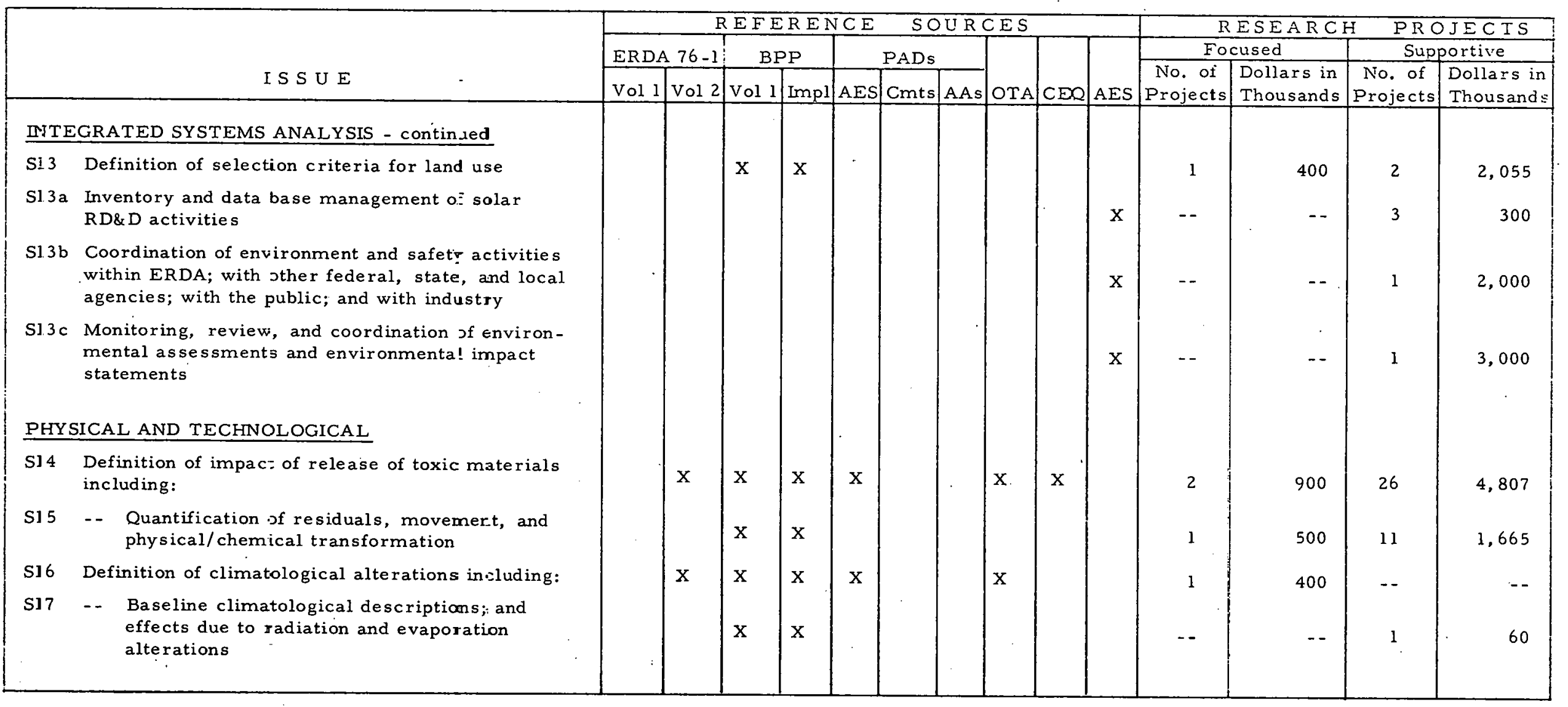


TABLE 7-2

MAJOR ISSUES - SOLAR

(continued)

\begin{tabular}{|c|c|c|c|c|c|c|c|c|c|c|c|c|c|c|c|}
\hline \multirow{3}{*}{\multicolumn{2}{|c|}{ I S S U E }} & \multicolumn{10}{|c|}{ REFERENCE } & \multirow{2}{*}{\multicolumn{2}{|c|}{$\begin{array}{l}\text { RESEARCF } \\
\text { Focused }\end{array}$}} & \multicolumn{2}{|c|}{ PROJECTS } \\
\hline & & \multicolumn{2}{|c|}{ ERDA $76-1$} & \multicolumn{2}{|c|}{ BPP } & \multicolumn{3}{|c|}{ PADs } & \multirow[b]{2}{*}{ OTA } & \multirow[b]{2}{*}{$\mathrm{CEQ}$} & \multirow[b]{2}{*}{ AES } & & & \multicolumn{2}{|c|}{ Supportive } \\
\hline & & Vol 1 & Vol 2 & Vol 1 & Impl & AES & Cmts & AAs & & & & $\begin{array}{c}\text { No. of } \\
\text { Projects }\end{array}$ & $\begin{array}{l}\text { Dollars in } \\
\text { Thousands }\end{array}$ & $\begin{array}{c}\text { No. of } \\
\text { Projects }\end{array}$ & $\begin{array}{l}\text { Dollars in } \\
\text { Thous and s }\end{array}$ \\
\hline \multicolumn{16}{|c|}{ HEAL TH } \\
\hline S13 & $\begin{array}{l}\text { Definition of the impact of the release of toxic } \\
\text { effluents on health for: }\end{array}$ & & $\mathrm{x}$ & $\mathrm{x}$ & $\mathrm{x}$ & $\mathrm{x}$ & & & & $\mathrm{x}$ & & 1 & 400 & & 2,485 \\
\hline S1 7 & $\begin{array}{l}\text {-- Bioconversion (organic compounds, sulfates, } \\
\mathrm{NO}_{\mathrm{x}} \text {, trace elements, pesticides). }\end{array}$ & & $\mathrm{x}$ & $\mathrm{x}$ & $\mathrm{x}$ & & & & & & & -- & $\cdots$ & 46 & 6,758 \\
\hline $\mathrm{S20}$ & -- Photovoltaic (Ct, Si) & & $\mathrm{x}$ & $\mathrm{X}$ & $\mathrm{X}$ & & & & & & & -- & -- & 2 & 490 \\
\hline $\mathrm{S} 21$ & $\begin{array}{l}\text {-- Dose-effect of short and long term acute and } \\
\text { chronic exposuze on humans and animals }\end{array}$ & & & $\mathrm{x}$ & $\mathrm{x}$ & & & & & & & -- & - & 3 & 515 \\
\hline $\mathbf{s} 22$ & $\begin{array}{l}\text { Evaluation of impact of unprocessed wastes from } \\
\text { biomass. }\end{array}$ & & $\mathrm{x}$ & $\mathrm{x}$ & $\mathrm{x}$ & & & & & & & -- & -- & 4 & 1,026 \\
\hline \multicolumn{16}{|c|}{ ENVIRONMENT } \\
\hline S23 & Definition of impact of toxic material rəlease for: & & $\mathrm{x}$ & $\mathrm{x}$ & $\mathrm{x}$ & $\mathrm{x}$ & & & & & & 1 & 400 & 7 & 1,602 \\
\hline S24 & $\begin{array}{l}\text {-- Biomass (organic compounds, sulfates, } \mathrm{NO}_{\mathbf{x}} \text {, } \\
\text { pathogens) }\end{array}$ & & $\mathrm{x}$ & $\mathrm{x}$ & $\mathrm{x}$ & & & & & & & -- & -- & 17 & 5,180 \\
\hline S25 & -- Photovoltaic (Cd, Si, propane, eutectic salts) & & $\mathrm{X}$ & $\mathrm{x}$ & $\mathrm{x}$ & $\mathrm{X}$ & & & & & & -. & -- & - & \\
\hline & -- Adverse ecological effect & & & $\mathrm{x}$ & $\mathrm{x}$ & & & & & & & -- & -- & 10 & 2,035 \\
\hline
\end{tabular}


TABLE 7-2

MAJOR ISSUES - SOLAR

( continued)

\begin{tabular}{|c|c|c|c|c|c|c|c|c|c|c|c|c|c|c|c|}
\hline & \multirow[b]{3}{*}{ I S S U E } & \multicolumn{10}{|c|}{ REFERENCE } & \multirow{2}{*}{\multicolumn{2}{|c|}{\begin{tabular}{l|l} 
RESEARCH \\
Focused
\end{tabular}}} & \multirow{2}{*}{\multicolumn{2}{|c|}{$\frac{\text { PR OJECTS }}{\text { Supportive }}$}} \\
\hline & & \multicolumn{2}{|c|}{ ERDA $76-1$} & \multicolumn{2}{|c|}{ BPP } & \multicolumn{3}{|c|}{ PADs } & \multirow[b]{2}{*}{ OTA } & \multirow[b]{2}{*}{ CEQ } & \multirow[b]{2}{*}{ AES } & & & & \\
\hline & & Vol 1 & Vol 2 & Vol 1 & Impl & AES & Cmts & AAs & & & & $\begin{array}{c}\text { No. of } \\
\text { Projects }\end{array}$ & $\begin{array}{l}\text { Dollars in } \\
\text { Thousands }\end{array}$ & $\begin{array}{c}\text { No. of } \\
\text { Projects }\end{array}$ & $\begin{array}{l}\text { Dollars in } \\
\text { Thousands }\end{array}$ \\
\hline \multicolumn{2}{|c|}{ ENIVIRONMENT - continuəd } & & & & & & & & & & & & & & \\
\hline S27 & $\begin{array}{l}\text { Definition of impact of potential climate alterations } \\
\text { caused by albedo/wind disturbances, local heat } \\
\text { rejection, energy balance, combustion; pyrolysis, } \\
\text { and soil runoff including: }\end{array}$ & & $\mathrm{X}$ & $\mathrm{X}$ & $\mathrm{X}$ & $\mathrm{X}$ & $\mathrm{X}$ & & $\mathrm{X}$ & & & -- & & 2 & 200 \\
\hline$\$ 23$ & -- Impact on local biota & & & $\mathrm{x}$ & $\mathrm{x}$ & & & & & & & -- & - & 12 & 2,553 \\
\hline $52 \cdot 7$ & $\begin{array}{l}\text { Definition of impact of developments on aquatic and } \\
\text { terrestrial biota for: }\end{array}$ & & $\mathrm{X}$ & $\mathrm{X}$ & $\mathrm{x}$ & $\mathrm{x}$ & & & & & & -- & $\cdots$ & 9 & 3,575 \\
\hline S30 & $\begin{array}{l}\text {-- Biomass (organic compounds, sulf ates, } \\
\text { pesticides, pathogens) }\end{array}$ & & & $\mathrm{x}$ & $\mathrm{x}$ & & & & & & & - & $\cdots$ & 6 & 2,981 \\
\hline S3 I & -- Photovoltaic (CA, Si, propane, eutectic salts) & & $\mathrm{x}$ & $\mathrm{X}$ & $\mathrm{X}$ & & & & & & & -- & -- & -- & -- \\
\hline S3? & Evaluation of biomass waste disposal techniques & & $\mathrm{X}$ & $\mathrm{x}$ & $\mathrm{x}$ & $\mathrm{x}$ & & & & & & -- & $\cdot--$ & 1 & 40 \\
\hline S3.3 & $\begin{array}{l}\text { Assurance of long-term productivity of tree } \\
\text { farming including: }\end{array}$ & & & & & & & $\mathrm{x}$ & $\mathrm{x}$ & & & 4 & 971 & 1 & 40 \\
\hline S31 & -. Resin production & & & & & & & & $\mathrm{x}$ & & & 1 & 214 & 1 & 40 \\
\hline S35 & $\begin{array}{l}\text { Investigations of basic photosynthesis processes } \\
\text { for biomass }\end{array}$ & & $\mathrm{x}$ & & & $\mathrm{x}$ & & & $\mathrm{X}$ & & & 37 & 4,290 & 7 & 949 \\
\hline S36 & $\begin{array}{l}\text { Determination of impact of wind energy disturbances } \\
\text { on wild. life and bird population }\end{array}$ & & & & $\mathrm{X}$ & & & & & & & $-\cdots$ & -- & $=-$ & - - \\
\hline
\end{tabular}



A summary of the planned FY 78 AES research program which has been categorized as "Geothermal" is presented in Table $8-1$. It is evident that approximately 40 percent of the focused research program is in the environmental effects area which emphasizes the ecological impact of the energy development. In the supportive projects, the major support is from Overview and Assessment where investigations of such areas as.determination of methods for socioeconomic impact assessment and strategies for managing socioeconomic impacts are epplicable to geothermal issues.

A correlation of the planned Geothermal projects with environmental issues is presented in Table 8-2. 
TA3LE 8-1. GEOTHERMAL RESEARCH SUMMARY

\begin{tabular}{|c|c|}
\hline \multicolumn{2}{|c|}{ Focused } \\
\hline $\begin{array}{c}\text { Number of } \\
\text { Projects } \\
\end{array}$ & $\begin{array}{l}\text { Dollars in } \\
\text { Thousands }\end{array}$ \\
\hline
\end{tabular}

Environmental

Physical and Technological

Educâtion and Training

Environmental Control Technalo

Safety, Standards, and Compliance

TOTAL
Research

4

3

9

Projects

\begin{tabular}{ll} 
Supportive* \\
$\begin{array}{cc}\text { Number of } & \text { Dollars in } \\
\text { Projects } & \text { Thousands }\end{array}$ \\
\hline
\end{tabular}

632

34

14,015

340

2,114

1,660

500

2

1

$\underline{\underline{22}}$
3

-

$=$

125

5,371
12

1

34

$-$

$\frac{-}{\underline{81}}$
1,695

130

4,925

$-$

20,765

* These values are only fractionally applicable to this energy form. 
TABLE 8-2

MAJOR ISSUES - GEOTHERMAL

\begin{tabular}{|c|c|c|c|c|c|c|c|c|c|c|c|c|c|c|c|}
\hline \multirow{3}{*}{\multicolumn{2}{|c|}{ I S S U E }} & \multicolumn{10}{|c|}{ REFERENCE } & \multirow{2}{*}{\multicolumn{2}{|c|}{\begin{tabular}{l|} 
RESEARCH \\
Focused
\end{tabular}}} & \multirow{2}{*}{\multicolumn{2}{|c|}{ PROJICIS }} \\
\hline & & \multicolumn{2}{|c|}{ ERDA $76-1$} & \multicolumn{2}{|c|}{$\mathrm{BPP}$} & \multicolumn{3}{|c|}{ PADs } & \multirow[b]{2}{*}{ OTA } & \multirow[b]{2}{*}{ CE2 } & \multirow[b]{2}{*}{ AES } & & & Supportive & \\
\hline & & Vol 1 & Vol 2 & Vol 1 & Impl & AES & Cmts & AAs & & & & $\begin{array}{c}\text { No. of } \\
\text { Projects }\end{array}$ & $\begin{array}{l}\text { Dollars in } \\
\text { Thousards }\end{array}$ & $\begin{array}{c}\text { No. of } \\
\text { Projects }\end{array}$ & $\begin{array}{l}\text { Dollars in } \\
\text { Thousands }\end{array}$ \\
\hline \multicolumn{2}{|c|}{ INTEGRATED SYSTEMS ANALYSIS } & & & & & & & & & & & & & & \\
\hline 31 & $\begin{array}{l}\text { Evaluation of physical and social constraints } \\
\text { to geothermal developments }\end{array}$ & & $\mathrm{X}$ & & & & & & $\mathrm{X}$ & & & 3 & 607 & 7 & 1,485 \\
\hline 32 & $\begin{array}{l}\text { Modification of EIS requirements and federal } \\
\text { and state policies to stimulate exploration }\end{array}$ & & $\mathrm{x}$ & & & & & $\mathrm{X}$ & $\mathrm{x}$ & & & -- & -- & -- & -- \\
\hline 33 & $\begin{array}{l}\text { Definition of analpsis and assessmen method- } \\
\text { ologies and site selection criteria }\end{array}$ & & $\mathrm{X}$ & & & & $\mathrm{x}$ & & $\mathrm{x}$ & & & 2 & 507 & 2 & 2,125 \\
\hline 34 & $\begin{array}{l}\text { Establishment of uniformity between federal, } \\
\text { state, and local regulations }\end{array}$ & & $\mathrm{X}$ & & & & & $\mathrm{x}$ & & & & -- & -- & 10 & 5,725 \\
\hline 35 & $\begin{array}{l}\text { Establishment and coordination of E\&S standards } \\
\text { and guidelines including: }\end{array}$ & $\mathrm{x}$ & $\mathrm{X}$ & & & & $\mathrm{x}$ & & & & & -- & -- & 14 & 6,130 \\
\hline 36 & -- Consideration of impact analysis & & & & & & & $\mathrm{x}$ & & & & -- & -- & 2 & 555 \\
\hline 37 & - Consideration of occupational saf $ə t y$ & & & & $\mathrm{x}$ & $\mathrm{x}$ & & & & & & - - & -- & 5 & 775 \\
\hline 38 & $\begin{array}{l}\text { - Consideration of Clean Air and Water Quality } \\
\text { Act compliance }\end{array}$ & & & & $\mathrm{x}$ & $\mathrm{x}$ & & & & & & -- & -- & 1 & 80 \\
\hline$=9$ & - - Consideration of accident prevention & & & & $\mathrm{x}$ & & & & & & & -- & - & 3 & 345 \\
\hline 310 & $\begin{array}{l}\text { Conduct baseline and operational measurements } \\
\text { of gases and trace element emissions }\end{array}$ & & & & $\mathrm{X}$ & & & & & & & -- & - & 3 & 2,140 \\
\hline 311 & Conduct baseline measurements at potential sites & $\mathrm{X}$ & & & $\mathrm{X}$ & & & & & & & 3 & 1,545 & 3 & 2,190 \\
\hline
\end{tabular}


TABLE 8-2

MAJOR ISSUES - GEOTHERMAL

(continued)

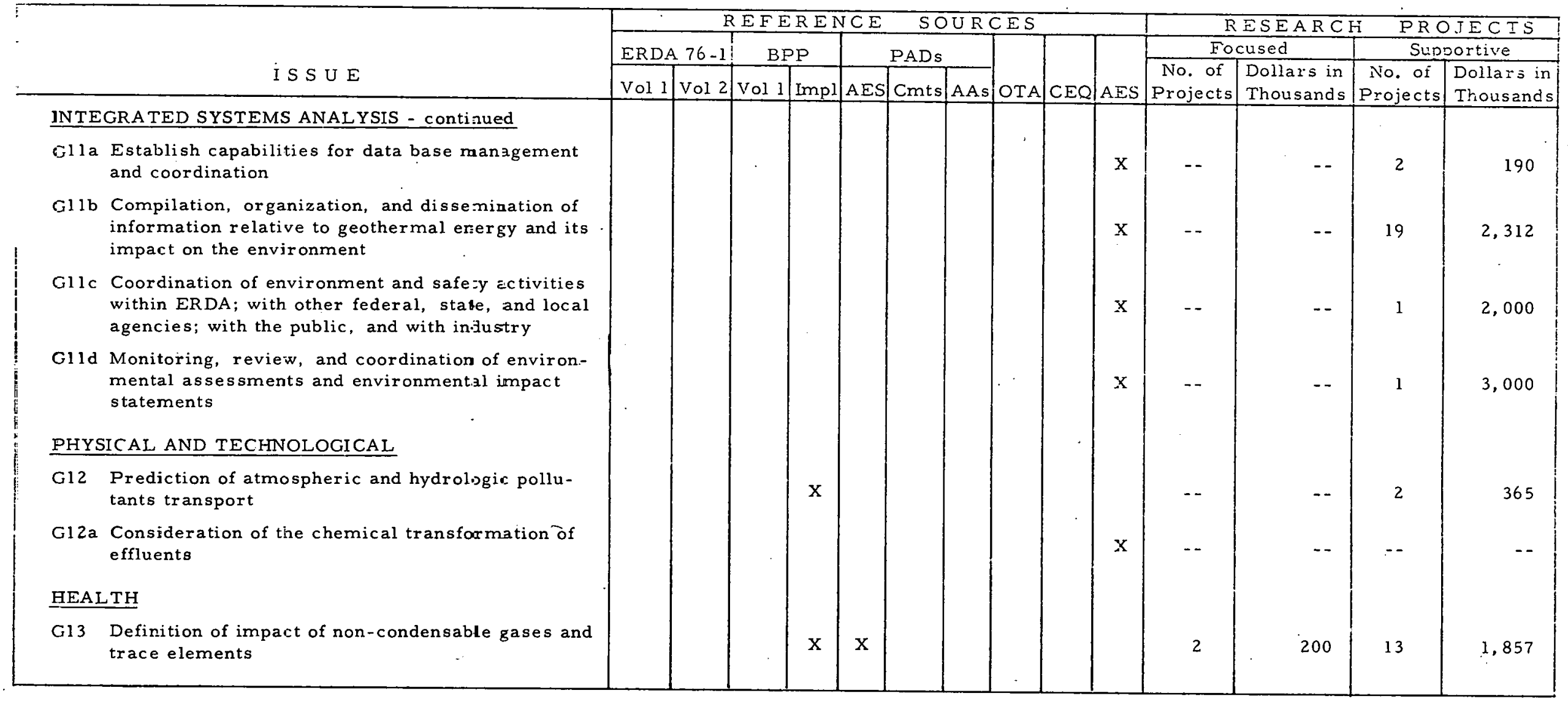


TABLE 8-2

MAJOR ISSUES - GEOTHERMAI

(continued)

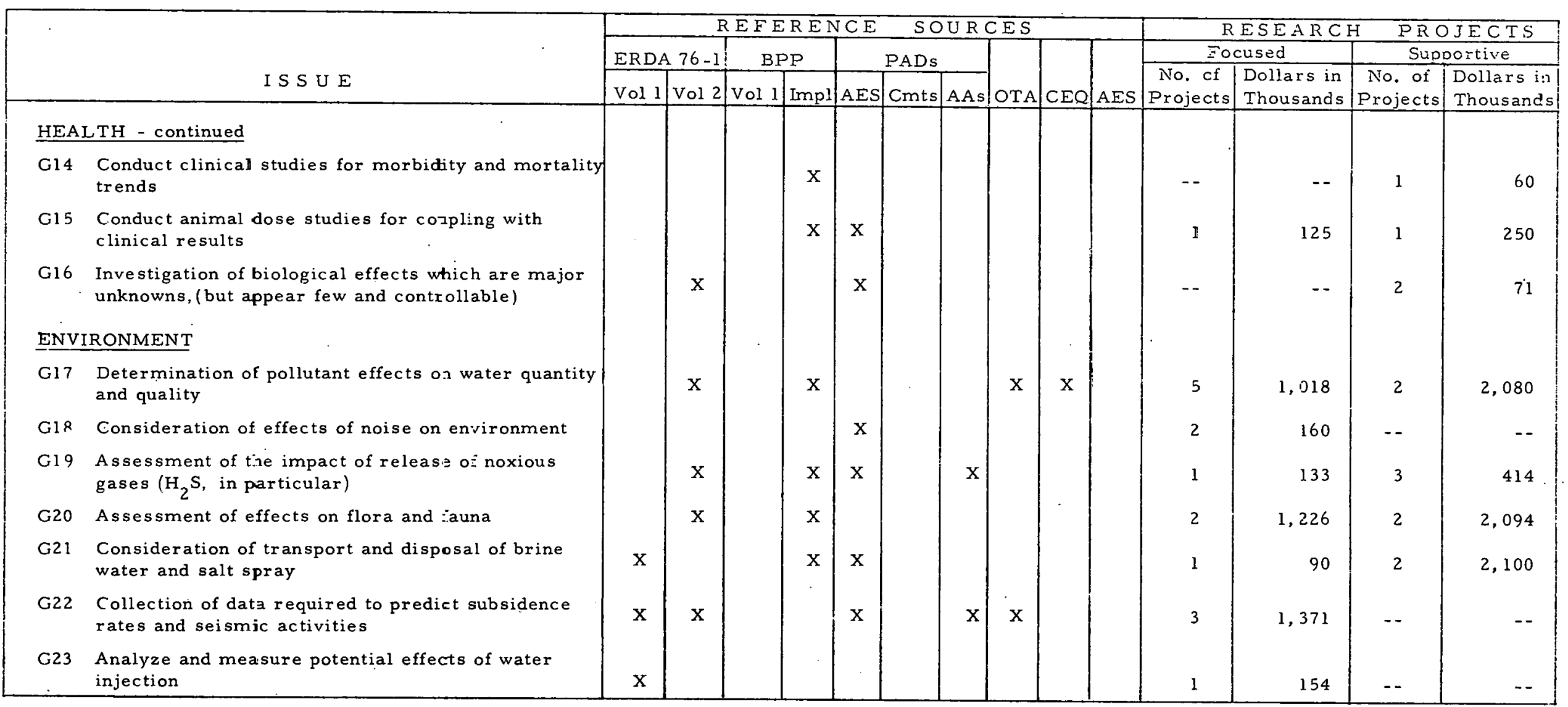


TABLE 8-2

MAJOR ISSUES - GEOTHERMAL

(continued)

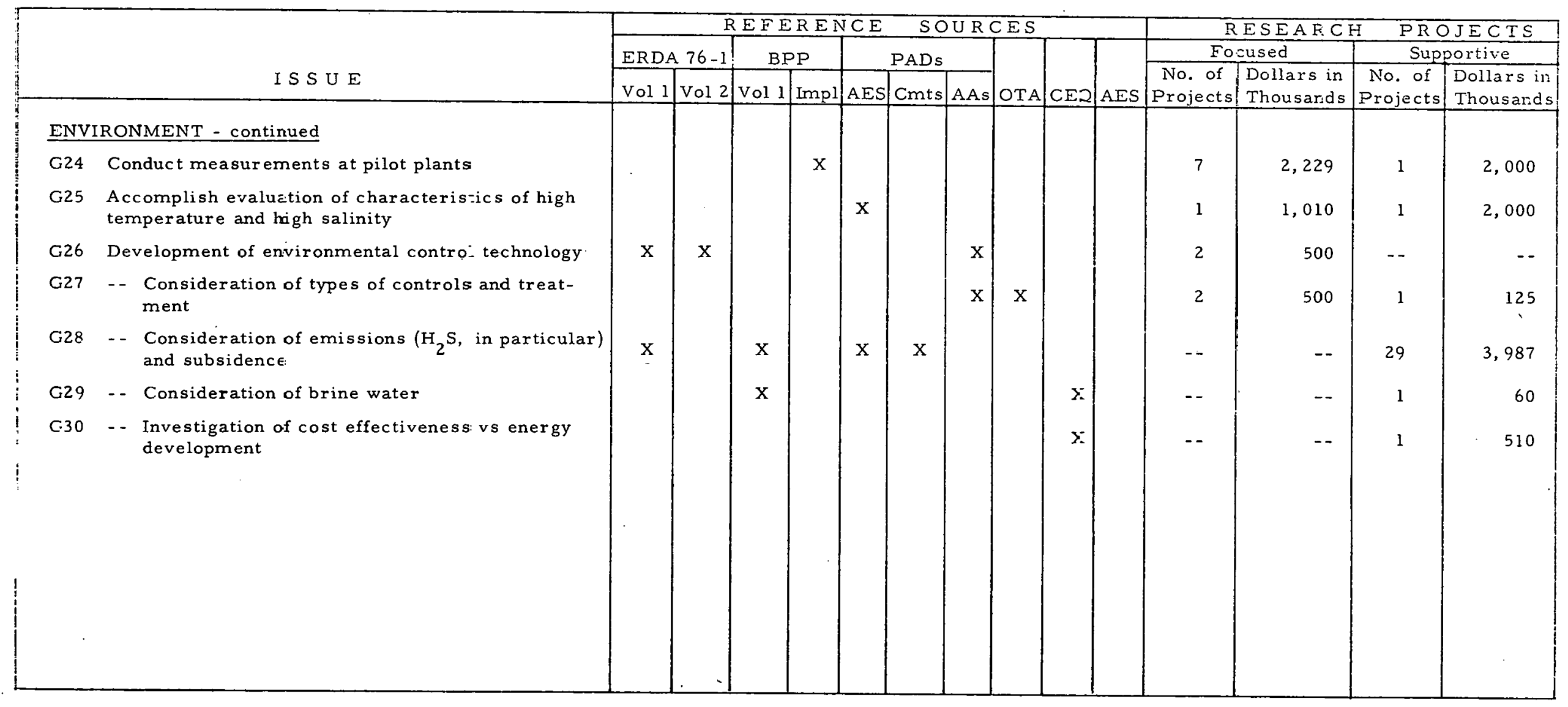




\section{SECTION 9}

\section{HYDR OELECTRIC}

A summary of the planned FY 78 AES research projects which have been categorized as "Hydroelectric" is presented in Table 9-1. The planned funding for Overview and Assessment is intended for integrated aralyses and overview of environmental studies within ERDA, including socioeconomic impacts. In the Health and Environmental area the programs concern themselves with health effects of reservoirs and ecological impact on rivers.

The correlation of tie Hydroelectric research to the major environmental issues drawn from ERDA documentation is presented in Table $9-2$. 
TABLE 9-1. HYDROELECTRIC RESEARCH SUMMARY

Research

\section{Subprogram}

Overview and Assessment

Health and Biological

Environmental

Physical and Technological

Education and Training

Environmental Control Technology

Safety, Standards, and Compliance TOTAL

*These values are only fracticnally applicable to this energy form.

\begin{tabular}{|c|c|c|c|}
\hline \multicolumn{2}{|c|}{ Focused } & \multicolumn{2}{|c|}{ Supportive* } \\
\hline $\begin{array}{c}\text { Number of } \\
\text { Projects } \\
\end{array}$ & $\begin{array}{l}\text { Dollars in } \\
\text { Thousands } \\
\end{array}$ & $\begin{array}{c}\text { Number of } \\
\text { Projects } \\
\end{array}$ & $\begin{array}{l}\text { Dollars in } \\
\text { Thousands }\end{array}$ \\
\hline 1 & 1,000 & 34 & 14,010 \\
\hline 1 & 86 & - & - \\
\hline 1 & 87 & - & - \\
\hline- & - & - & - \\
\hline- & - & - & - \\
\hline- & - & - & - \\
\hline- & - & - & - \\
\hline$\underline{3}$ & $\underline{1,173}$ & 34 & 14,010 \\
\hline
\end{tabular}


TABLE 9-2

MAJOR ISSUES - HYDROELECTRIC

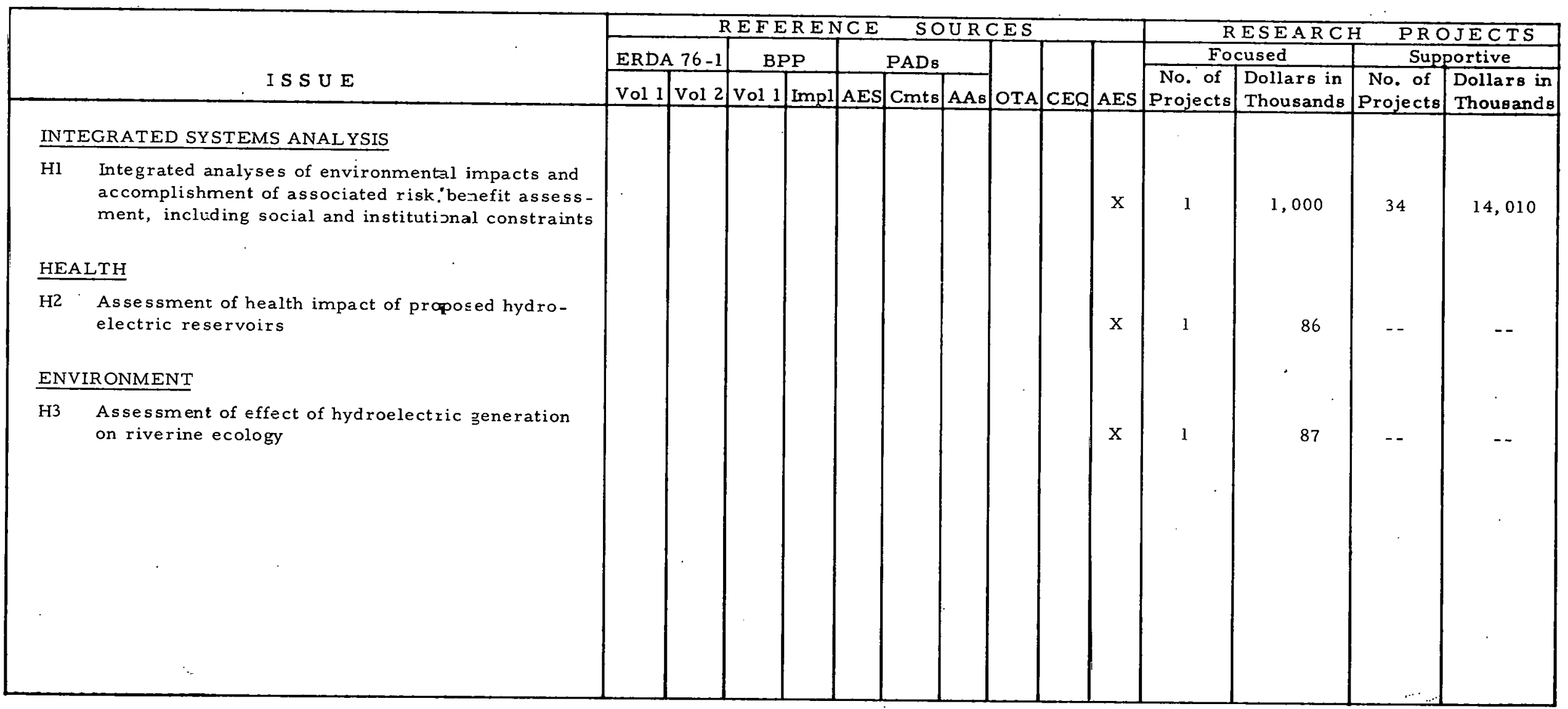



A summary of the planned FY 78 AES research which has been categorized as "Conservation" is presented in Table 10-1. It is to be noted that the major emphasis of the program is in the Environmental Control Technology and Physical and Technological areas. The reduced level of Conservation focused research shoun here compared with that presented in other AES budget summaries results from the separate break out of Hydroelectric research and the inclusion in Solar of biomass work previously assigned to Conse rvation.

The correlation of the Conservation research to the major environmental issues drawn from ERDA documentation is presented in Table $10-2$. 
TAELE $10-1$. CONSERVATION RESEARCH SUMMARY

\begin{tabular}{|c|c|c|c|c|}
\hline \multirow{3}{*}{$\begin{array}{cc} & 1 \\
\text { Subprogram }\end{array}$} & \multicolumn{2}{|r|}{ Research } & \multicolumn{2}{|l|}{ Projects } \\
\hline & \multicolumn{2}{|c|}{ Focused } & \multicolumn{2}{|c|}{ Supportive* } \\
\hline & $\begin{array}{c}\text { Number of } \\
\text { Projects }\end{array}$ & $\begin{array}{l}\text { Dollars in } \\
\text { Thousands }\end{array}$ & $\begin{array}{l}\text { Number of } \\
\text { Projects }\end{array}$ & $\begin{array}{l}\text { Dollars in } \\
\text { Thousands }\end{array}$ \\
\hline Overview and Assessment & 1 & 471 & 35 & 15,010 \\
\hline Health and Biological & - & - & 20 & 2,944 \\
\hline Environmental & 1 & 50 & 25 & 4,348 \\
\hline Physical and Technological & 3 & 723 & 35 & 5,055 \\
\hline Education and Training & - & - & - & - \\
\hline Environmental Sontrol Technology & 5 & 626 & - & - \\
\hline Safety, Standards, and Compliance & - & - & - & - \\
\hline TOTAL & $\underline{10}$ & 1,870 & $\underline{115}$ & 27,357 \\
\hline $\begin{array}{l}\text { *These values aze only fractionally } \\
\text { applicable to this energy form. }\end{array}$ & & . & & \\
\hline
\end{tabular}


TABLE 10-2

MAJOR ISSUES - CONSERVATION

\begin{tabular}{|c|c|c|c|c|c|c|c|c|c|c|c|c|c|c|c|}
\hline \multirow{3}{*}{\multicolumn{2}{|c|}{ I S S U E }} & \multicolumn{10}{|c|}{ REFERENCE } & \multirow{2}{*}{\multicolumn{4}{|c|}{$\begin{array}{l}\text { F.ESEARCH } \\
\text { Focused }\end{array}$}} \\
\hline & & \multicolumn{2}{|c|}{ ERDA $76-1$} & \multicolumn{2}{|c|}{$\mathrm{BPP}$} & \multicolumn{3}{|c|}{ PADs } & \multirow[b]{2}{*}{ OTA } & \multirow[b]{2}{*}{ CEQ } & \multirow[b]{2}{*}{ AES } & & & & \\
\hline & & Vol 1 & Vol 2 & Vol l & Impl & AES & Cmts & AAs & & & & $\begin{array}{c}\text { No. of } \\
\text { Projects }\end{array}$ & $\begin{array}{l}\text { Dollars in } \\
\text { Thousands }\end{array}$ & \begin{tabular}{|c|} 
No. of \\
Projects \\
\end{tabular} & $\begin{array}{l}\text { Dollars in } \\
\text { Thousands }\end{array}$ \\
\hline $\mathrm{Vl}$ & $\begin{array}{l}\text { Definition of the national, regional, and local } \\
\text { socioeconomic impact of development including }\end{array}$ & $\mathrm{x}$ & $\mathrm{X}$ & $\mathrm{x}$ & $\mathrm{x}$ & $\mathrm{x}$ & $\mathrm{X}$ & $\mathrm{X}$ & $\mathrm{X}$ & $\mathrm{x}$ & & 1 & $4 ? 1$ & 9 & 2,950 \\
\hline$\sqrt{2}$ & $\begin{array}{l}\text { - Capital availability to support higher risk and } \\
\text { higher cost demonstrations aimec at com- } \\
\text { mercialization- end use and electric }\end{array}$ & $\mathrm{x}$ & $\mathrm{x}$ & & & & & & & & & -- & -- & -- & -- \\
\hline V3 & $\begin{array}{l}\text { Public acceptance of life cycle costs rather } \\
\text { than initizl cost - end use. }\end{array}$ & $\mathrm{X}$ & $\mathrm{X}$ & & & & & & & & & 1 & 471 & -- & -- \\
\hline V4 & $\begin{array}{l}\text {-- Market penetration which may be impeded by } \\
\text { environmental, human health, and safety } \\
\text { conditions }\end{array}$ & $\mathrm{x}$ & & & & & & & & & & 1 & 471 & 1 & 50 \\
\hline V5 & $\begin{array}{l}\text {-- Life style which may be affected by reduced } \\
\text { gasoline consumption }\end{array}$ & $\mathrm{X}$ & & & & & & & & & & 1 & 471 & -- & - \\
\hline v6 & $\begin{array}{l}\text { Investigation of new standards and regulations which } \\
\text { may deter vendors - end use and electricity } \\
\text { storage }\end{array}$ & $\mathrm{X}$ & $\mathrm{x}$ & $X$ & & & & & & & & - - & -- & - - & - \\
\hline V7 & $\begin{array}{l}\text { Definition of special facilities and modifications to } \\
\text { local permits and labor practices required for } \\
\text { stored energy vehicles }\end{array}$ & & $\mathrm{x}$ & & & & & & - & & & - & -- & 1 & 50 \\
\hline v8 & $\begin{array}{l}\text { Definition of impact on band requirements due to } \\
\text { high voltage overhead transmission lines }\end{array}$ & & $\mathrm{x}$ & & & & & & & & & 1 & 75 & -- & -- \\
\hline
\end{tabular}


TABLE 10-2

MAJOR ISSUES - CONSERVATION

(continued)

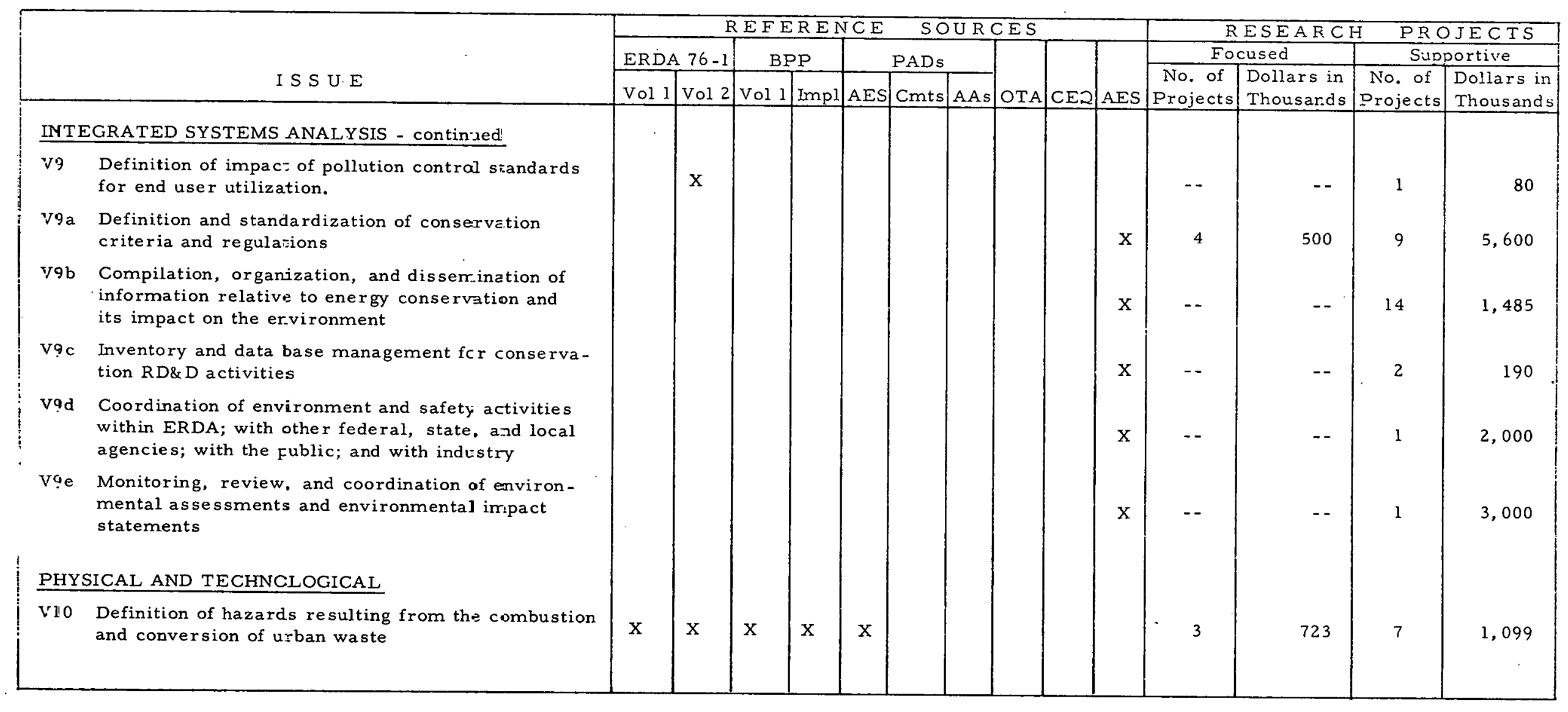


TABLE $10-2$

MAJOR ISSUES - CONSERVATION

(continued)

\begin{tabular}{|c|c|c|c|c|c|c|c|c|c|c|c|c|c|c|c|}
\hline & \multirow[b]{3}{*}{ I S S U E } & \multicolumn{10}{|c|}{ REFERENCE } & \multicolumn{4}{|c|}{ RESEARCH } \\
\hline & & \multicolumn{2}{|c|}{ ERDA $76-1$} & \multicolumn{2}{|c|}{ BPP } & \multicolumn{3}{|c|}{ PADs } & \multirow[b]{2}{*}{ OTA } & \multirow[b]{2}{*}{$C E Q$} & \multirow[b]{2}{*}{ AES } & \multicolumn{2}{|c|}{ Focused } & \multicolumn{2}{|c|}{ Supportive } \\
\hline & & Vol 1 & Vol 2 & Vol 1 & Impl & AES & Cmts & AAs & & & & \begin{tabular}{|c|} 
No. of \\
Projects
\end{tabular} & $\begin{array}{l}\text { Dollars in } \\
\text { Thousands }\end{array}$ & \begin{tabular}{|c|} 
No. of \\
Projects \\
\end{tabular} & $\begin{array}{l}\text { Dollars in } \\
\text { Thousands }\end{array}$ \\
\hline \multicolumn{16}{|c|}{ PHYSICAL AND TECHNOLOGICAL - cont nued } \\
\hline & -- Quantification of emissions and waste pollutants & & & $\mathrm{x}$ & $\mathrm{x}$ & & & & & & & 3 & 723 & 43 & 8,648 \\
\hline V12. & $\begin{array}{l}\text { Development of models of potential pollutants } \\
\text { (SO } \mathrm{SO}_{\mathrm{x}} \text {, particulates) movement and fate }\end{array}$ & & & $\mathrm{x}$ & $\mathrm{x}$ & & & & & & & -- & -- & 16 & 4,332 \\
\hline \multicolumn{16}{|c|}{ HÉALTH } \\
\hline VI 3 & $\begin{array}{l}\text { Definition of health hazards from the ccmbustion } \\
\text { and conversion of urban waste (toxic emissions } \\
\text { and pathogens) including: }\end{array}$ & & & $\mathrm{x}$ & $\mathrm{x}$ & $\mathrm{x}$ & & & & & & -- & -- & 14 & 2,448 \\
\hline V14 & -- Screening for biological activity & & & $\mathrm{X}$ & $\mathrm{X}$ & & & & & & & -- & -- & 9 & 2,779 \\
\hline V15 & -- Determination of impact on population & & & $\mathrm{x}$ & $\mathrm{x}$ & & & & & & & - & -- & 2 & 150 \\
\hline V16 & $\begin{array}{l}\text { Consideration of impact of reduced air flow in } \\
\text { builcings including: }\end{array}$ & $\mathrm{x}$ & $\mathrm{x}$ & $\mathrm{X}$ & $\mathrm{X}$ & $\mathrm{x}$ & & & & & & 1 & 500 & 1 & 75 \\
\hline V17 & $\begin{array}{l}\text { Increased exposure to toxic agents (carbons, } \\
\text { pyrolysis, aerosols, } \mathrm{CO}_{2} \text {, toxic fibers from } \\
\text { insulation materials) }\end{array}$ & $X$ & & $\mathrm{x}$ & $\mathrm{X}$ & & & & & & & -- & -- & 2 & 135 \\
\hline V18 & $\begin{array}{l}\text {-- Increased exposure to communicable diseases } \\
\text { (viruses) }\end{array}$ & & & $\mathrm{x}$ & $\mathrm{x}$ & & & & & & & -- & -- & 1 & 75 \\
\hline V19 & Definition of transport and control of emissions ( $\left.\mathrm{SO}_{x}\right)$ & $x$ & $X$ & & & & & & & $\mathrm{x}$ & & 1 & 500 & -- & -- \\
\hline
\end{tabular}


TABLE 10-2

MAJOR ISSUES - CONSERVATION

(continued)

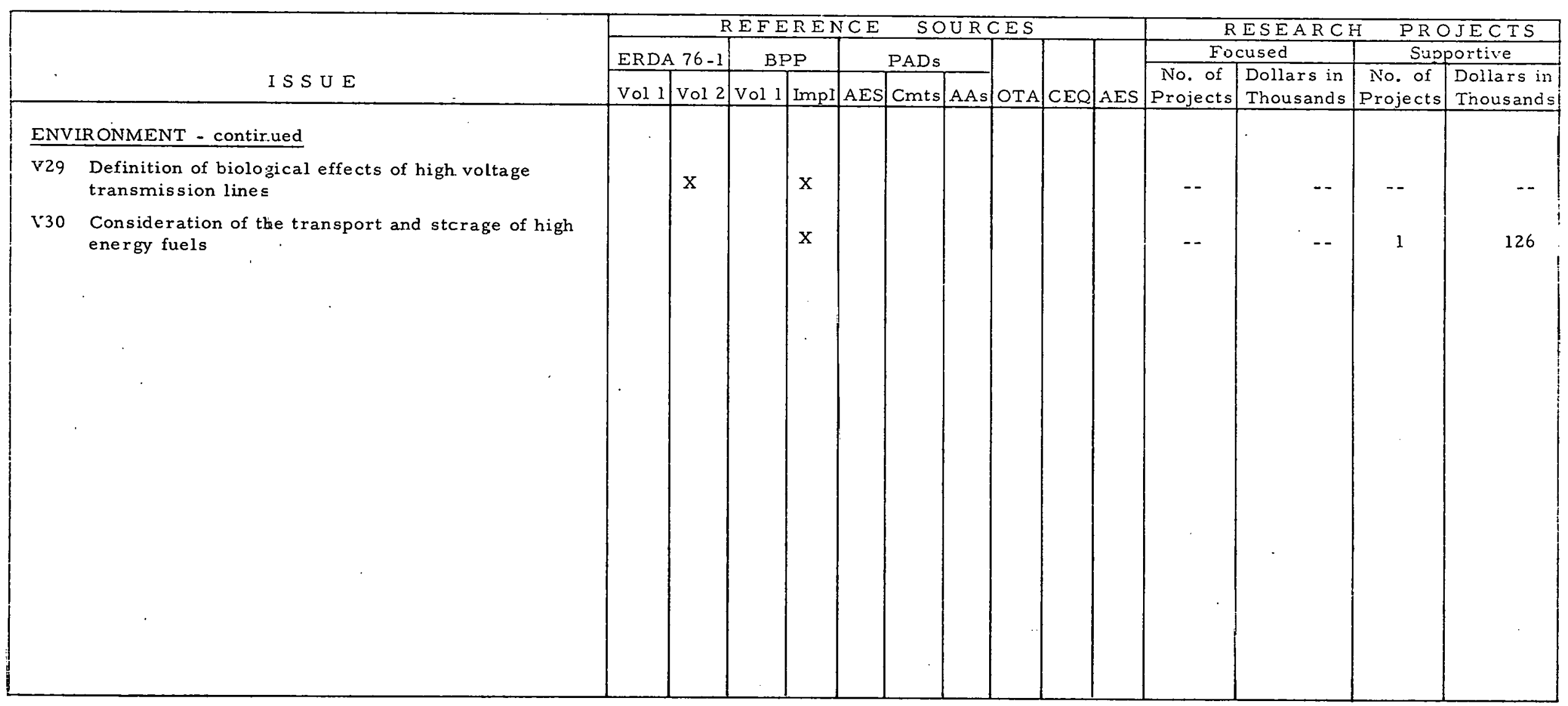




\section{SECTION 11}

FISSION

A summary of the planned FY 78 AES research, which has been categorized as "Fission" is presented in Table $11-i$. The major thrust of the planned Fission program is directed toward the Health and Biological and the Environmental Control Technology areas. Note that approximately 72 percent of the overall program is orierted toward these two areas. A major portion cf the Health and Biological projects concern animal experiments and the impact of radiation.

As also indicated in Table 11-1, the major portion of supportive research falls into the Overview and Assessment, Health and Biological, and Environmental projects.

The correlation of the planned Fission research to the environmental issues drawn from ERDA documentation is shown in Table $11-2$. 
TABLE $11-1$. FISSION RESEARCH SUMMARY

Research

\begin{tabular}{|c|c|c|c|}
\hline \multicolumn{2}{|c|}{ Focused } & \multicolumn{2}{|c|}{ Supportive* } \\
\hline $\begin{array}{c}\text { Number of } \\
\text { Projects } \\
\end{array}$ & $\begin{array}{l}\text { Dollars in } \\
\text { Thousands }\end{array}$ & $\begin{array}{c}\text { Number of } \\
\text { Projects }\end{array}$ & $\begin{array}{l}\text { Dollars in } \\
\text { Thousands }\end{array}$ \\
\hline 5 & 905 & 37 & 15,170 \\
\hline 162 & 38,599 & 61 & 10,860 \\
\hline 82 & 12,057 & 108 & 14,814 \\
\hline 49 & 7,075 & 15 & 1,962 \\
\hline 6 & 1,320 & - & - \\
\hline 46 & 24,260 & 11 & 1,614 \\
\hline 15 & 2,725 & 19 & 2,180 \\
\hline 365 & 86,941 & 251 & 46,600 \\
\hline
\end{tabular}

*These values are only fractionally applicable to this energy form. 
TABLE $11-2$

MAJOR ISSUES - FISSION

\begin{tabular}{|c|c|c|c|c|c|c|c|c|c|c|c|c|c|c|c|}
\hline \multirow{3}{*}{\multicolumn{2}{|c|}{ I S S U E }} & \multicolumn{10}{|c|}{ REFERENCE } & \multirow{2}{*}{\multicolumn{2}{|c|}{ RESEARCF }} & \multirow{2}{*}{\multicolumn{2}{|c|}{$\begin{array}{l}\text { PROJECTS } \\
\text { Supportive }\end{array}$}} \\
\hline & & \multicolumn{2}{|c|}{ ERDA $76-1$} & \multicolumn{2}{|c|}{ BPP } & \multicolumn{3}{|c|}{ PADs } & \multirow[b]{2}{*}{ OTA } & \multirow[b]{2}{*}{ CEQ } & \multirow[b]{2}{*}{ AES } & & & & \\
\hline & & Vol 1 & Vol 2 & Vol l & Impl & AES & Cmts & AAs & & & & $\begin{array}{c}\text { No. of } \\
\text { Projects }\end{array}$ & $\begin{array}{l}\text { Dollars in } \\
\text { Thousands }\end{array}$ & $\begin{array}{c}\text { No. of } \\
\text { Projects }\end{array}$ & $\begin{array}{l}\text { Dollars in } \\
\text { Thousand } s\end{array}$ \\
\hline \multicolumn{2}{|c|}{ IIJTEGRATED SYSTEMS ANALYSIS } & . & & & & & & & & & & & & & \\
\hline F1 & $\begin{array}{l}\text { Definition of criteria, regulations, and standards } \\
\text { including: }\end{array}$ & & . & & & & & & $\mathrm{x}$ & & & 7 & 1,135 & 16 & 7,210 \\
\hline $\mathrm{F} 2$ & $\begin{array}{l}\text { Determination of adequacy of curren: radiation } \\
\text { protection standards for plutonium and other } \\
\text { transuranics }\end{array}$ & & & & & & & & $\mathrm{x}$ & & & 61 & 24,181 & 9 & 1,464 \\
\hline F3 & $\begin{array}{l}\text { Standardization of regulations and "standards" } \\
\text { needed among states on such subjects as: }\end{array}$ & & $\mathrm{x}$ & & & & & & $\mathrm{x}$ & & & -- & -- & 1 & 100 \\
\hline F4 & $\begin{array}{l}\text { - Allowable ruclide release, cocling water } \\
\text { uptake, temperature increase, discharges } \\
\text { to streams }\end{array}$ & & $\mathrm{X}$ & & & & & & & & & 2 & 455 & 2 & 2,100 \\
\hline F5 & $\begin{array}{l}\text { - Development of criteria for waste forms and } \\
\text { packaging }\end{array}$ & $\mathrm{X}$ & $\mathrm{x}$ & & & & & & & & & 1 & 140 & 2 & 225 \\
\hline F6 & $\begin{array}{l}\text { Development of LMFBR plant safety standards } \\
\text { and regulations (acceptable to public and } \\
\text { various regulatory agencies) }\end{array}$ & & $\mathrm{x}$ & & & & & $\mathrm{x}$ & & & & 2 & 550 & 4 & 444 \\
\hline F7 & $\begin{array}{l}\text { Development and experimental verification of } \\
\text { probabilistic models of fuel cycle prozessing } \\
\text { accidents }\end{array}$ & & $\mathrm{x}$ & & & & & $x$ & & & & 10 & 2,542 & 5 & 544 \\
\hline F8 & $\begin{array}{l}\text { Accomplishment of economic-engineering studies } \\
\text { on most cost effec ive ways to improve plant safety }\end{array}$ & & & & & & & $x$ & & & & 6 & 1,957 & 4 & 305 \\
\hline
\end{tabular}


TABLE 11-2

MAJOR ISSUES - FISSION

(continued)

\begin{tabular}{|c|c|c|c|c|c|c|c|c|c|c|c|c|c|c|c|}
\hline \multirow{3}{*}{\multicolumn{2}{|c|}{ J S S U E }} & \multicolumn{10}{|c|}{ REFERENCE } & \multirow{2}{*}{\multicolumn{2}{|c|}{$\frac{\text { RESEARCI }}{\text { Focused }}$}} & \multicolumn{2}{|c|}{ PROJECTS } \\
\hline & & \multicolumn{2}{|c|}{ ERDA $76-1$} & \multicolumn{2}{|c|}{$\mathrm{BPP}$} & \multicolumn{3}{|c|}{ PADs } & \multirow[b]{2}{*}{ OTA } & \multirow[b]{2}{*}{ CEQ } & \multirow[b]{2}{*}{ AES } & & & \multicolumn{2}{|c|}{ Supportive } \\
\hline & & Vol 1 & Vol 2 & Vol 1 & Impl & AES & Cmts & AAs & & & & $\begin{array}{c}\text { No. of } \\
\text { Projects }\end{array}$ & $\begin{array}{l}\text { Dollars in } \\
\text { Thousands }\end{array}$ & $\begin{array}{l}\text { No. of } \\
\text { Projects }\end{array}$ & $\begin{array}{l}\text { Dollars in } \\
\text { Thousands }\end{array}$ \\
\hline \multicolumn{2}{|r|}{ INTEGRATED SYSTEMS ANALYSIS - continaed } & & & & & & & & & & & & & & \\
\hline F9 & $\begin{array}{l}\text { Determination of public perceptions vs actual safety, } \\
\text { health, and envirommental impacts }\end{array}$ & & & $\mathrm{x}$ & $\mathrm{x}$ & & & $\mathrm{x}$ & & & & 7 & 1,215 & 10 & 3,385 \\
\hline F10 & $\begin{array}{l}\text { Determination of E-S background data Eor nuclear } \\
\text { ships and offshore sites }\end{array}$ & & $\mathrm{x}$ & & & & & & & & & 7 & 1,353 & 30 & 7,158 \\
\hline FII & $\begin{array}{l}\text { Development o a central data source to provide } \\
\text { fission technology programs with current, balanced } \\
\text { information on environmental and heal-h impacts }\end{array}$ & & $\mathrm{X}$ & & & & & & & & & 30 & 12,338 & 18 & 2,316 \\
\hline F 12 & $\begin{array}{l}\text { Quantification of impacts of radioisotope releases } \\
\text { (accidental or chronic) considering: }\end{array}$ & & $\mathrm{X}$ & & $\mathrm{x}$ & & & & $\mathrm{x}$ & & & 42 & 7,017 & 40 & 8,419 \\
\hline F13 & -- Disposition anc resuspension of particles & & $\mathrm{X}$ & & $\mathrm{x}$ & & & & $\mathrm{x}$ & & & 16 & 2,453 & 13 & 4,307 \\
\hline F14 & -- Food web analyses & & $\mathrm{x}$ & & $\mathrm{x}$ & & & & $\mathrm{x}$ & & & 28 & 3,571 & 46 & 7,133 \\
\hline FI 5 & -- Inhalation stud:.es & & $\mathrm{X}$ & & $\mathrm{x}$ & & & & $\mathrm{x}$ & & & 23 & 9,254 & 3 & 340 \\
\hline F16 & -- Organ burdens vs effects & & $\mathrm{X}$ & & $\mathrm{x}$ & & & & $\mathrm{x}$ & & & 37 & 12,041 & -- & -- \\
\hline$F 17$ & -- Rates of movement - pathways & & $\mathrm{X}$ & & $\mathrm{X}$ & & & & $\mathrm{x}$ & & & 29 & 5,637 & 56 & 12,798 \\
\hline$F 18$ & $\begin{array}{l}\text {-- Chemical transformations and zomes of } \\
\text { accumulation }\end{array}$ & & $\mathrm{x}$ & & $\mathrm{X}$ & & & & $\mathrm{x}$ & & & 24 & 3,523 & 28 & 4,003 \\
\hline F19 & $\begin{array}{l}\text { Determination of reprocessing facility radionuclide } \\
\text { releases needed }\end{array}$ & & & & & & & & $\mathrm{x}$ & & & -- & -- & 3 & 2,584 \\
\hline
\end{tabular}


TABLE 11-2

MAJOR ISSUES - FISSION

(continued)

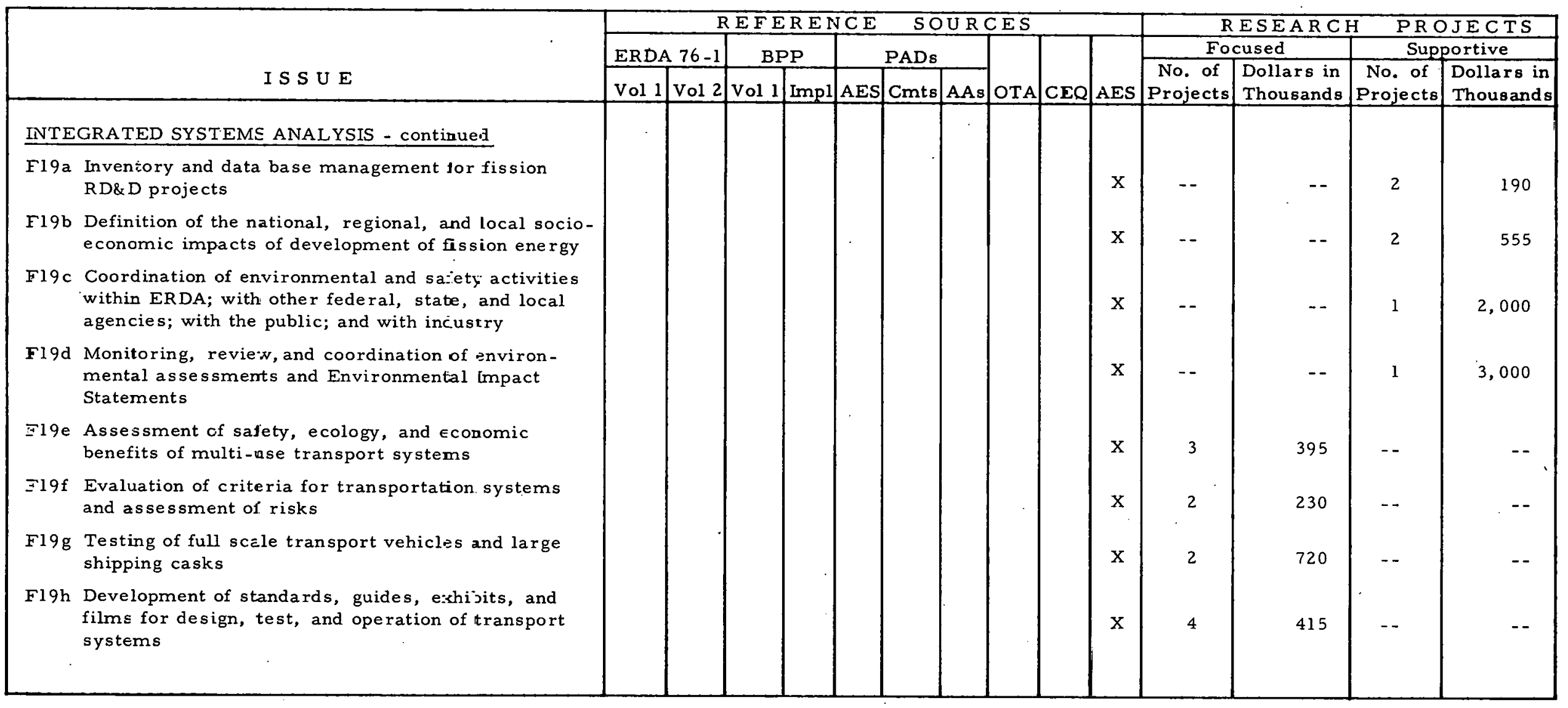


TABLE 11-2

MAJOR ISSUES - FISSION

(continued)

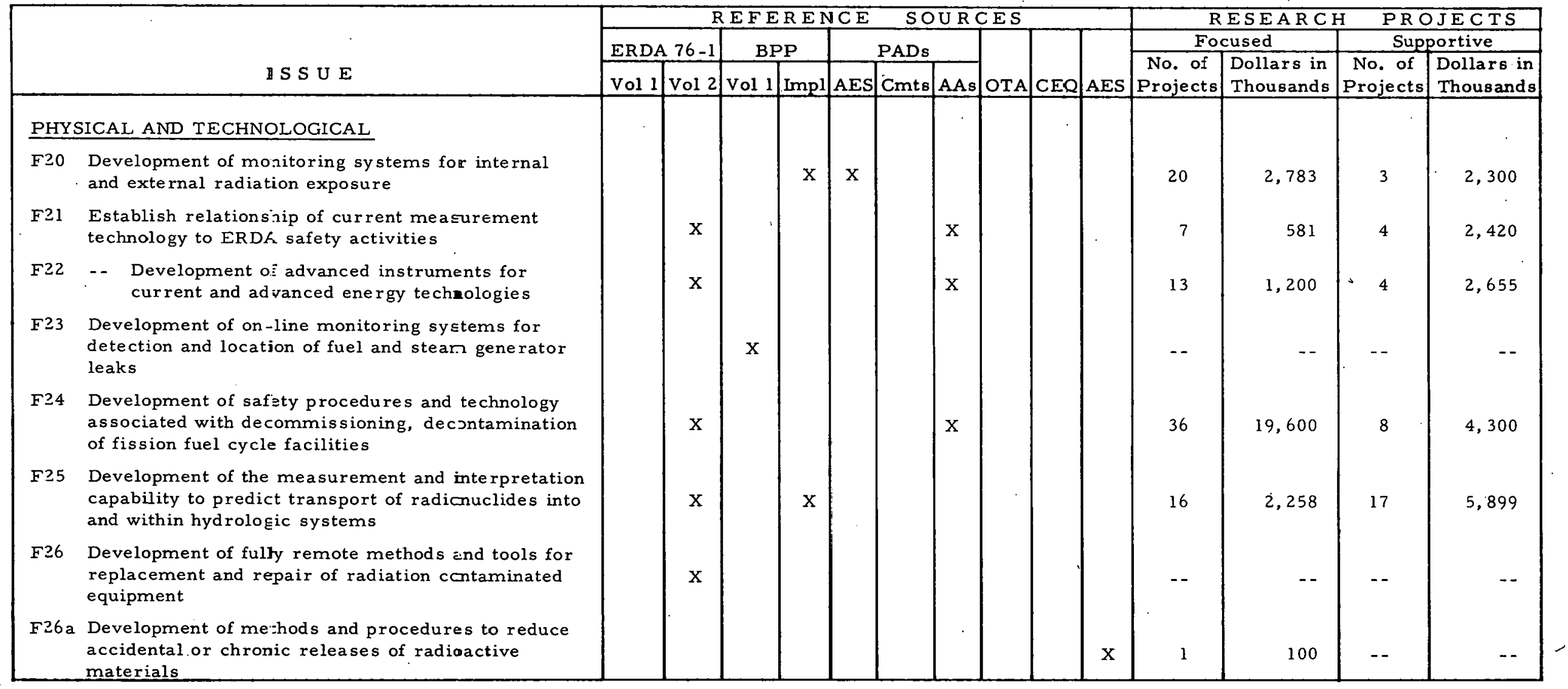


TABLE $11-2$

MAJOR ISSUES - FISSION

(continued)

\begin{tabular}{|c|c|c|c|c|c|c|c|c|c|c|c|c|c|c|c|}
\hline \multirow{3}{*}{\multicolumn{2}{|c|}{ I S S U E }} & \multicolumn{10}{|c|}{ REFERENCE } & \multirow{2}{*}{\multicolumn{2}{|c|}{$\begin{array}{l}\text { RESEARCF } \\
\text { Focused }\end{array}$}} & \multicolumn{2}{|c|}{ PROJECTS } \\
\hline & & \multicolumn{2}{|c|}{ ERDA $76-1$} & \multicolumn{2}{|c|}{$\mathrm{BPP}$} & \multicolumn{3}{|c|}{ PADs } & \multirow[b]{2}{*}{ OTA } & \multirow[b]{2}{*}{ CEO } & \multirow[b]{2}{*}{ AES } & & & \multicolumn{2}{|c|}{ Supportive } \\
\hline & & Vol 1 & Vol 2 & Vol 1 & Impl & AES & Cmts & AAs & & & & $\begin{array}{c}\text { No. of } \\
\text { Projects }\end{array}$ & $\begin{array}{l}\text { Dollars in } \\
\text { Thousands }\end{array}$ & $\begin{array}{c}\text { No. of } \\
\text { Projects }\end{array}$ & $\begin{array}{l}\text { Dollars in } \\
\text { Thousands }\end{array}$ \\
\hline \multicolumn{2}{|c|}{ HEALTH } & & & & & & & & & & & & & & \\
\hline F27 & $\begin{array}{l}\text { Development and validation of rapid biclogical and } \\
\text { automated cytochemical screening teckniques to } \\
\text { identify hazardous zadiation conditions and agents }\end{array}$ & & $\mathrm{x}$ & & & & & & & & & 9 & 918 & 7 & 1,205 \\
\hline F28 & $\begin{array}{l}\text { Development of early indicators of fission damage } \\
\text { to human populatiors }\end{array}$ & & $\mathrm{x}$ & & & & . & & & & & 7 & 1,050 & 11 & 1,963 \\
\hline F29 & $\begin{array}{l}\text { Investigation of radiation impact on plitonium } \\
\text { worke } r \text { epidemiology }\end{array}$ & & & $\mathrm{X}$ & & & & & & & & 20 & 8,793 & 3 & 690 \\
\hline F30 & $\begin{array}{l}\text { Identification of human sub-populations' suscep- } \\
\text { tibility to radiation damage }\end{array}$ & & $\mathrm{x}$ & & & & & & & & & 20 & 8,783 & 8 & 1,701 \\
\hline F31 & $\begin{array}{l}\text { Clarification of human dose-response =elationship } \\
\text { for low level radiation exposure }\end{array}$ & & & & $\mathrm{x}$ & $\mathrm{x}$ & $\mathrm{X}$ & & & & & 72 & 28,576 & 11 & 3,900 \\
\hline F32 & $\begin{array}{l}\text { Accumulation of data on human organ ruclide } \\
\text { burdens vs effects }\end{array}$ & & $\mathrm{X}$ & $\mathrm{X}$ & $\mathrm{X}$ & & & & & & & 13 & 1,846 & 29 & 4,007 \\
\hline F33 & $\begin{array}{l}\text { Accomplishment of basic research on mechanisms } \\
\text { of radiation damage and repair including }\end{array}$ & & $\mathrm{X}$ & $\mathrm{X}$ & & $\mathrm{X}$ & & & & & & 30 & $.3,715$ & 19 & 2,697 \\
\hline$F 34$ & $\begin{array}{l}\text {-- Extrapolation cf dose-effects relalions from } \\
\text { model systems to man }\end{array}$ & & & & & $\mathrm{X}$ & & & & & & 65 & 19,096 & 17 & 3,691 \\
\hline F35 & $\begin{array}{l}\text { Definition of methodology on entire problem of } \\
\text { extrapolation of animal data to man }\end{array}$ & & $x$ & & $\mathrm{x}$ & $\mathrm{X}$ & & & & & & 56 & 17,968 & 10 & 1,542 \\
\hline
\end{tabular}


TABLE 11-2

MAJOR ISSUES - FISSION

(continued)

\begin{tabular}{|c|c|c|c|c|c|c|c|c|c|c|c|c|c|c|c|}
\hline \multirow{3}{*}{\multicolumn{2}{|c|}{ I S S U E }} & \multicolumn{10}{|c|}{ REFERENCE } & \multirow{2}{*}{\multicolumn{2}{|c|}{\begin{tabular}{l|l} 
RESEA R C H \\
Focused
\end{tabular}}} & \multirow{2}{*}{\multicolumn{2}{|c|}{$\begin{array}{l}\text { PR OJECTS } \\
\text { Supportive }\end{array}$}} \\
\hline & & \multicolumn{2}{|c|}{ ERDA $76-1$} & \multicolumn{2}{|c|}{ BPP } & \multicolumn{3}{|c|}{ PADs } & \multirow[b]{2}{*}{ OTA } & \multirow[b]{2}{*}{$C E Q$} & \multirow[b]{2}{*}{ AES } & & & & \\
\hline & & Vol 1 & Vol 2 & Vol 1 & Impl & AES & Cmts & AAs & & & & $\begin{array}{c}\text { No. of } \\
\text { Projects }\end{array}$ & $\begin{array}{l}\text { Dollars in } \\
\text { Thousands }\end{array}$ & $\begin{array}{c}\text { No. of } \\
\text { Projects }\end{array}$ & $\begin{array}{l}\text { Dollars in } \\
\text { Thousands }\end{array}$ \\
\hline \multicolumn{2}{|c|}{ HEALTH - continued } & - & & & & & & & & & & & & & \\
\hline F36 & $\begin{array}{l}\text { Accomplishment of basic research on radiation } \\
\text { interaction with living cells }\end{array}$ & & $\mathrm{x}$ & & & & & & $\mathrm{x}$ & & & 21 & 2,476 & 33 & 5,122 \\
\hline F36a & $\begin{array}{l}\text { Investigation of cormbating detrimental effects of } \\
\text { internal emitters and heavy metals }\end{array}$ & & & & & & & & & & $\mathrm{x}$ & -- & -- & -- & -- \\
\hline \multicolumn{2}{|c|}{ ENVIRONMENT } & & & & & & & & & & & & & & \\
\hline F37 & $\begin{array}{l}\text { Definition of high level and low level waste disposal } \\
\text { impacts including: }\end{array}$ & $\mathrm{x}$ & $\mathrm{x}$ & & $\mathrm{x}$ & & & & & & & 26 & 3,394 & 17 & 1,796 \\
\hline & $\begin{array}{l}\text { Less soluble, more monolithic ( } s=f e r \text { ) waste } \\
\text { forms }\end{array}$ & $\mathrm{x}$ & $\mathrm{x}$ & & $\mathrm{x}$ & & & & & & & 3 & $2 \leq 9$ & 2 & 1,042 \\
\hline F39 & $\begin{array}{l}\text { Complete geologic studies of deep-stable } \\
\text { formations for waste disposal sites - location, } \\
\text { quantity, stabi-ity }\end{array}$ & $\mathrm{x}$ & & & $\mathrm{x}$ & & & & & & & 1 & 140 & 1 & 100 \\
\hline$F 40$ & $\begin{array}{l}\text { Reduction of measurement uncertainties of low } \\
\text { concentration, high volume waste streams }\end{array}$ & & $\mathrm{x}$ & & & & & & & & & 1 & 140 & 3 & 195 \\
\hline & $\begin{array}{l}\text {-- Development of methods and procedures for } \\
\text { handling high level wastes }\end{array}$ & & & & & & & $\mathrm{x}$ & & & & 4 & 4,065 & -- & -- \\
\hline F42 & $\begin{array}{l}\text { Definition of LMFBR co-location (Nuclear Park) } \\
\text { siting problems including: }\end{array}$ & & & & & & & & $\mathrm{X}$ & & & - & -- & 1 & 85 \\
\hline$F \leq 3$ & $=$ Seismic problems, all sites & & $\mathrm{x}$ & & & & & & $\mathrm{x}$ & & & 1 & 120 & 3 & 300 \\
\hline
\end{tabular}


TABLE $11-2$

MAJOR ISSUES - FISSION

(continued)

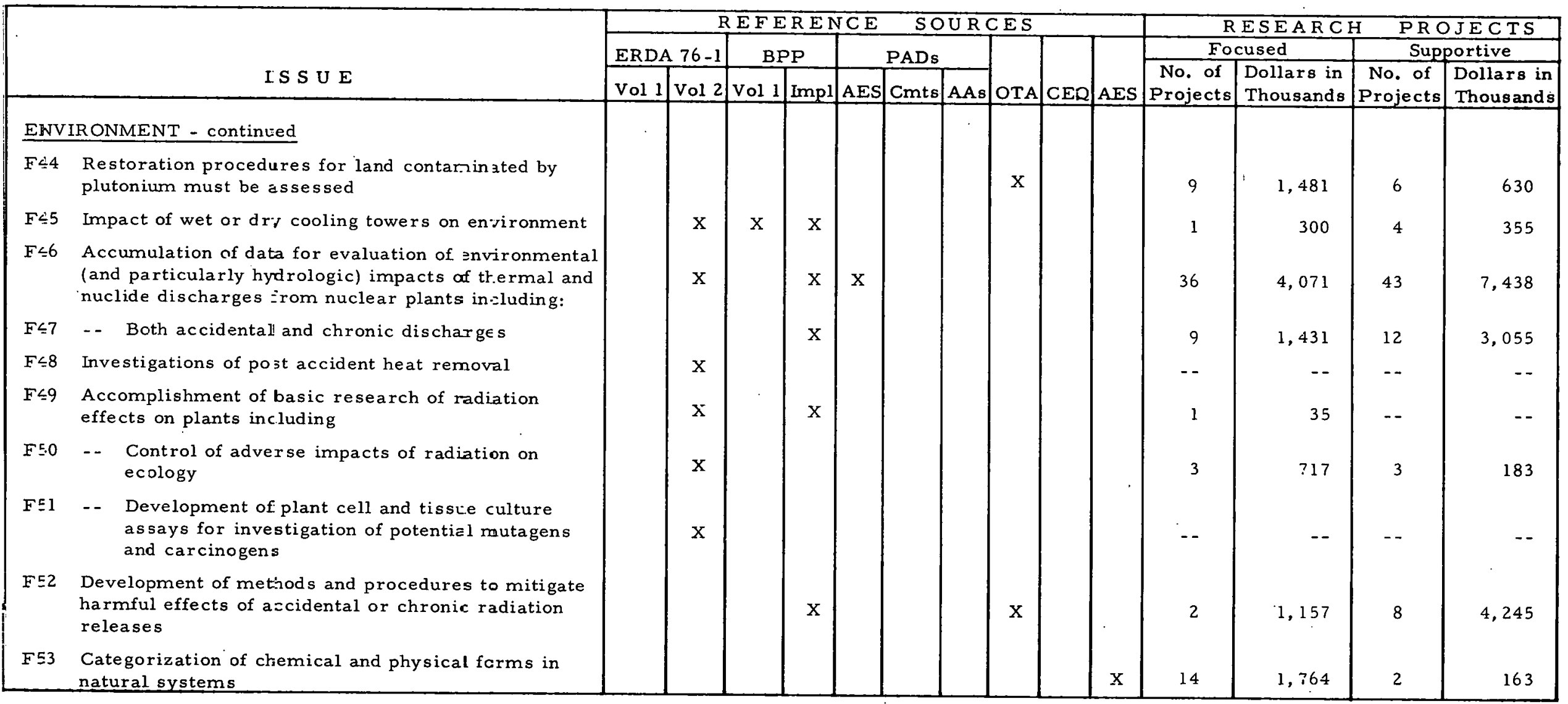


TABLE $11-2$

MAJOR ISSUES - FISSION

(continued)

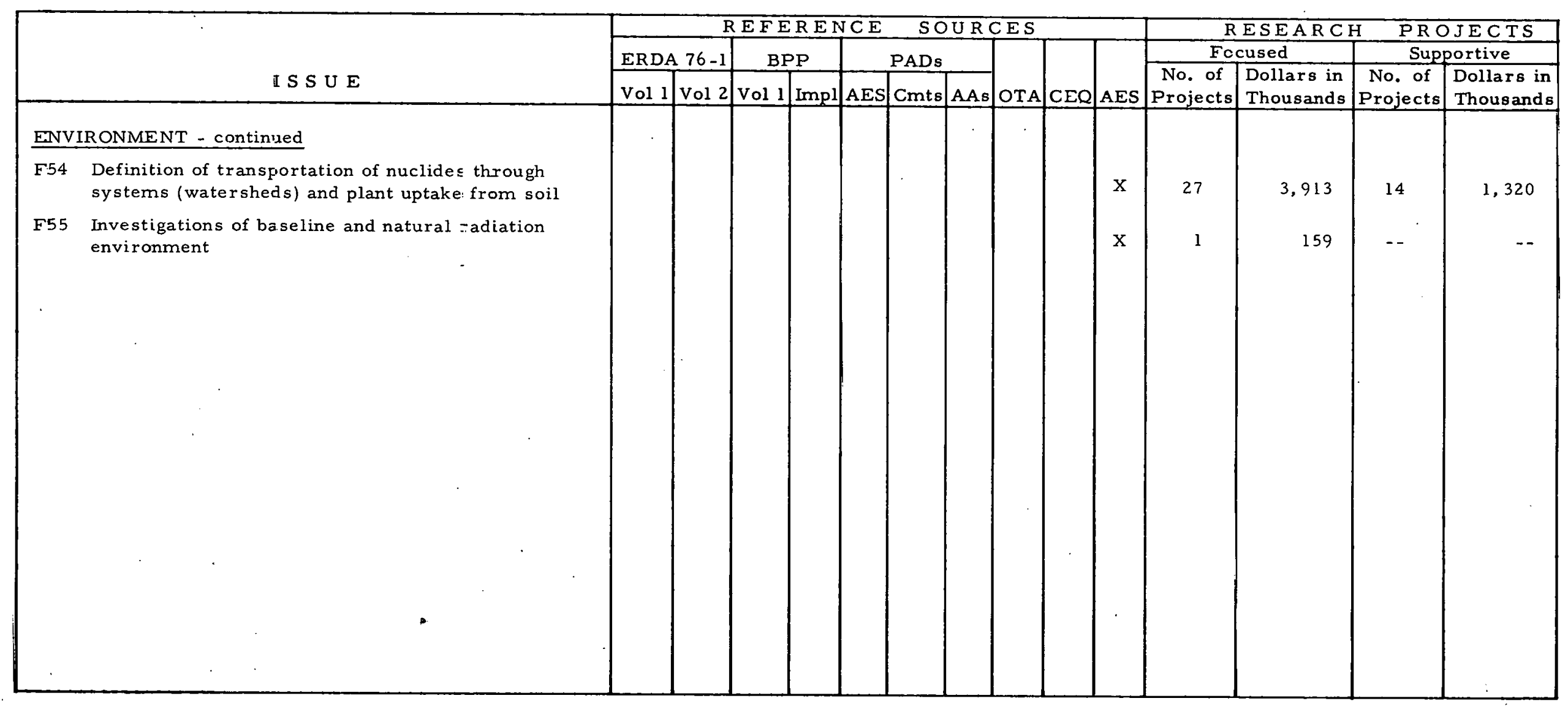




\section{SECTION 12}

\section{FUSION}

A summary of the planned FY 78 AES research which has been categorized as "Fusion" is presented in Table 12-1. The magnitude of the "focused" research funds when compared to other energy forms is low. This is attributed to: 1) the fact that fusion energy development is in an early stage and potential environmental impacts are yet to be defined and 2) considerable elementary research applicable to Fusion is also applicable to Fission and has been or will be conducted as Fission focused research. The large level of supportive research shown in Table 12-1 reflects the applicability to Fusion issues of a significant fraction of the planned Fission researzh.

The correlation of the planned Fusion related research with the environmental is sues expressed in ERDA documentation is shown in Table 12-2. 
TABLE 12-1. FUSION RESEARCH SUMMARY

\section{Subprogram}

Ove rview and Assessment

Health and Biological

\section{Environmental}

Physical and Technological

Education and Training

Environmental Control Technolosy

Safety, Standards, and Compliance

$$
\text { TOTAL }
$$

\footnotetext{
* These values are only fractiorally
} applicable to this energy form.
Research

Projects

\begin{tabular}{|c|c|c|c|}
\hline \multicolumn{2}{|c|}{ Focused } & \multicolumn{2}{|c|}{ Supportive* } \\
\hline $\begin{array}{c}\text { Number of } \\
\text { Projects } \\
\end{array}$ & $\begin{array}{l}\text { Dollars in } \\
\text { Thousands }\end{array}$ & $\begin{array}{c}\text { Number of } \\
\text { Projects } \\
\end{array}$ & $\begin{array}{l}\text { Dollars in } \\
\text { Thousands }\end{array}$ \\
\hline 1 & 80 & 34 & 14,875 \\
\hline 6 & 703 & 21 & 4,209 \\
\hline 6 & 575 & 3 & 440 \\
\hline 1 & 100 & - & - \\
\hline - & - & - & - \\
\hline- & - & 11 & 1,614 \\
\hline 1 & 100 & 3 & 145 \\
\hline$\underline{\underline{15}}$ & 1,558 & 72 & 21,283 \\
\hline
\end{tabular}


TABLE $12-2$

MAJOR ISSUES - FUSION

\begin{tabular}{|c|c|c|c|c|c|c|c|c|c|c|c|c|c|c|c|}
\hline \multirow{3}{*}{\multicolumn{2}{|c|}{ I S S U E }} & \multicolumn{10}{|c|}{ REFERENCE } & \multirow{2}{*}{\multicolumn{2}{|c|}{\begin{tabular}{|l|l} 
RESEARCH \\
Focused
\end{tabular}}} & \multirow{2}{*}{\multicolumn{2}{|c|}{$\begin{array}{c}\text { PR OJE CTS } \\
\text { Supportive } \\
\end{array}$}} \\
\hline & & \multicolumn{2}{|c|}{ ERDA $76-1$} & \multicolumn{2}{|c|}{ BPP } & \multicolumn{3}{|c|}{ PADs } & \multirow[b]{2}{*}{ OTA } & \multirow[b]{2}{*}{ CEQ } & \multirow[b]{2}{*}{ AES } & & & & \\
\hline & & Vol l & Vol 2 & Vol 1 & Impl & AES & Cmts & $\mathrm{AAs}$ & & & & \begin{tabular}{|c|} 
No. of \\
Projects \\
\end{tabular} & $\begin{array}{l}\text { Dollars in } \\
\text { Thousands }\end{array}$ & $\begin{array}{c}\text { No. of } \\
\text { Projects }\end{array}$ & $\begin{array}{l}\text { Dollars in } \\
\text { Thousands }\end{array}$ \\
\hline \multicolumn{2}{|c|}{ IN TEGRATED SYSTEMS ANALYSIS } & & & & & & & . & & & & & & & \\
\hline $\mathrm{U} 1$ & $\begin{array}{l}\text { Definition of env-ronmental advantages and eco- } \\
\text { nomic potential }\end{array}$ & & & & & & $\mathrm{x}$ & & & & & 1 & 80 & 6 & 2,730 \\
\hline $\mathrm{U} 2$ & $\begin{array}{l}\text { Coordination of E\&S plant standards and guide- } \\
\text { lines including: }\end{array}$ & & & & & $\mathrm{x}$ & $\mathrm{X}$ & & & & & -- & $\cdots$ & 17 & 6,145 \\
\hline U3 & -- Occupational safety & & & & & $\mathrm{X}$ & $\mathrm{x}$ & & & & & 2 & 180 & 7 & 665 \\
\hline $\mathrm{U} 4$ & -- Accident prevention & & & & & $\mathrm{X}$ & $\mathrm{X}$ & & & & & -- & -- & 3 & 170 \\
\hline U5 & -- Clean Air and Water Quality Act compliance & & & & & $\mathrm{x}$ & & & & & & -- & -- & 1 & 2,000 \\
\hline U6 & $\begin{array}{l}\text { Dissemination of information to transportation } \\
\text { offices concerning operational aspects including: }\end{array}$ & & & & & $\mathrm{x}$ & & & & & & -- & -- & 17 & 2,790 \\
\hline $\mathrm{U} 7$ & - - Transportation functions & & & & & $\mathrm{x}$ & & & & & & -- & -- & - & - \\
\hline $\mathrm{U} 8$ & - - Risk assessments & & & & & $\mathrm{x}$ & & & & & & 1 & 80 & 2 & 265 \\
\hline $\mathrm{U} 8 \mathrm{a}$ & $\begin{array}{l}\text { Compilation, organization, and dissemination of } \\
\text { information relative to fusion energy and its im- } \\
\text { pact on the environment }\end{array}$ & & & & & $\mathrm{x}$ & & & & & $\theta$ & -- & -- & 14 & 1,485 \\
\hline $\mathrm{U} 8 \mathrm{~b}$ & $\begin{array}{l}\text { Inventory and data base management for fusion } \\
\text { RD\&D activities }\end{array}$ & & & & & $\mathrm{x}$ & & & & & & -- & -- & 2 & 190 \\
\hline $\mathrm{U} 8 \mathrm{c}$ & $\begin{array}{l}\text { Definition of the national, regional, and local socio } \\
\text { socioeconomic impact of development of fusion } \\
\text { energy }\end{array}$ & & & & & $x$ & & & & & & -- & -- & -- & -- \\
\hline
\end{tabular}


TABLE $12-2$

MAJOR ISSUES - FUSION

(continued)

\begin{tabular}{|c|c|c|c|c|c|c|c|c|c|c|c|c|c|c|c|}
\hline \multirow{3}{*}{\multicolumn{2}{|c|}{$\bar{S}$ S U E }} & \multicolumn{10}{|c|}{ REFERENCE } & \multirow{2}{*}{\multicolumn{4}{|c|}{$\frac{\text { PROJECTS }}{\text { Supportive }}$}} \\
\hline & & \multicolumn{2}{|c|}{ ERDA $76-1$} & \multicolumn{2}{|c|}{ BPP } & \multicolumn{3}{|c|}{ PADs } & \multirow[b]{2}{*}{ OTA } & \multirow[b]{2}{*}{ CEQ } & \multirow[b]{2}{*}{ AES } & & & & \\
\hline & & Vol 1 & Vol 2 & Vol 1 & Impl & AES & Cmts & AAs & & & & $\begin{array}{c}\text { No. of } \\
\text { Projects }\end{array}$ & $\begin{array}{l}\text { Dollars in } \\
\text { Thousands }\end{array}$ & $\begin{array}{c}\text { No. of } \\
\text { Projects }\end{array}$ & $\begin{array}{l}\text { Dollars in } \\
\text { Thousands }\end{array}$ \\
\hline \multicolumn{2}{|r|}{ INTEGRATED SYSTEMS ANALYSIS - contir.ued } & & & & & & & & & & & & & & \\
\hline ¿ $8 \mathrm{~d}$ & $\begin{array}{l}\text { Coordination of environment and safety activities } \\
\text { within ERDA; with other federal, state, and local } \\
\text { agencies; with the public; and with inchustry }\end{array}$ & & & & & & & & & & $\mathrm{x}$ & -- & -- & 1 & 2,000 \\
\hline Ur8e & $\begin{array}{l}\text { Monitoring, review, and coordination of environ- } \\
\text { mental assessmen:s and Environmental lmpact } \\
\text { Statements }\end{array}$ & & & & & & & & & & $\mathrm{x}$ & $\because-$ & -- & 1 & 3,000 \\
\hline \multicolumn{2}{|c|}{ PHYSICAL AND TECHNOLOGICAL } & & . & & & & & & & & & & & & \\
\hline U9 & Investigations of safety technology inclucing: & & $\mathrm{x}$ & & & & & & & & & 1 & 100 & 3 & 170 \\
\hline 010 & $\begin{array}{l}\text { Completion of safety analysis reforts for } \\
\text { tritium handling }\end{array}$ & & $\mathrm{x}$ & & & & & & & & & -- & -- & -- & - \\
\hline $\mathrm{U} 12$ & $\begin{array}{l}\text { Definition of surplus contaminated facilities manage- } \\
\text { ment procedures }\end{array}$ & & & & & $\mathrm{x}$ & & & & & & -- & -- & 5 & 2,550 \\
\hline $\mathrm{U} 13$ & Examination of public safety requirements & & $\mathrm{x}$ & & & & & & & & & -- & -- & 3 & 500 \\
\hline
\end{tabular}


TABLE $12-2$

MAJOR ISSUES - FUSION

(continued)

\begin{tabular}{|c|c|c|c|c|c|c|c|c|c|c|c|c|c|c|c|}
\hline & \multirow[b]{3}{*}{ I S U E } & \multicolumn{10}{|c|}{ REFERENCE } & \multirow{2}{*}{\multicolumn{2}{|c|}{ Focused }} & \multicolumn{2}{|c|}{ PROJECTS } \\
\hline & & \multicolumn{2}{|c|}{ ERDA $76-1$} & \multicolumn{2}{|c|}{ BPP } & \multicolumn{3}{|c|}{ PADs } & \multirow[b]{2}{*}{ OTA } & \multirow[b]{2}{*}{ CEQ } & \multirow[b]{2}{*}{ AES } & & & \multicolumn{2}{|c|}{ Supportive } \\
\hline & & Vol 1 & Vol 2 & Vol 1 & Impl & AES & Cmts & AAs & & & & $\begin{array}{c}\text { No. of } \\
\text { Projects }\end{array}$ & $\begin{array}{l}\text { Dollars in } \\
\text { Thousands }\end{array}$ & $\begin{array}{c}\text { No. of } \\
\text { Projects }\end{array}$ & $\begin{array}{l}\text { Dollars in } \\
\text { Thousands }\end{array}$ \\
\hline \multicolumn{2}{|c|}{ HEALTH } & & & & & & & & & & & & & & \\
\hline U14 & $\begin{array}{l}\text { Consideration of physiological changes in workers } \\
\text { due to high voltage, high magnetic fields }\end{array}$ & & & $\mathrm{x}$ & & & & & & & & 2 & 385 & - & -- \\
\hline U15 5 & Establishment of dcse and dose rate ef & & & & & $\mathrm{x}$ & & & & & & 5 & 670 & 4 & 1,125 \\
\hline & $\begin{array}{l}\text { Definition of extrapolation techniques frorm animal } \\
\text { experimentation to man }\end{array}$ & & & & & $x$ & & & & & & 5 & 670 & 16 & 3,089 \\
\hline Ui7 & $\begin{array}{l}\text { Definition of biological modeling techniques for } \\
\text { impact analysis }\end{array}$ & & & & & $\mathrm{x}$ & & & & & & 7 & 730 & 18 & 3,224 \\
\hline \multicolumn{2}{|c|}{ ENVIRONMENT } & & & & & & & & & & & & & & \\
\hline Ui 8 & $\begin{array}{l}\text { Definition of impacl of reactor level hydrogen } \\
\text { plasmas }\end{array}$ & & $\mathrm{X}$ & & & & & & & & & -- & -. & - & -- \\
\hline Ui 9 & Definition of impact of magnetic fusion de ielopment & & $\mathrm{X}$ & & & & & & & & & - & -- & 1 & 100 \\
\hline $\mathrm{U} 20$ & $\begin{array}{l}\text { Investigation of hanjling and fire hazards of lithium } \\
\text { and tritium }\end{array}$ & & & $\mathrm{x}$ & & & & & & & & 3 & 304 & 2 & 159 \\
\hline $\mathrm{U} 21$ & $\begin{array}{l}\text { Development of biological modeling techniques for } \\
\text { impact analysis }\end{array}$ & & . & & & $\mathrm{x}$ & & & & & & 3 & 60 & 4 & 330 \\
\hline $\mathrm{U} 22$ & $\begin{array}{l}\text { Definition of offshoze siting impact on environment } \\
\text { required }\end{array}$ & & & & & $\mathrm{x}$ & & & & & & -- & - & 3 & 440 \\
\hline
\end{tabular}


TABLE $12-2$

MAJOR ISSUES - FUSION

(continued)

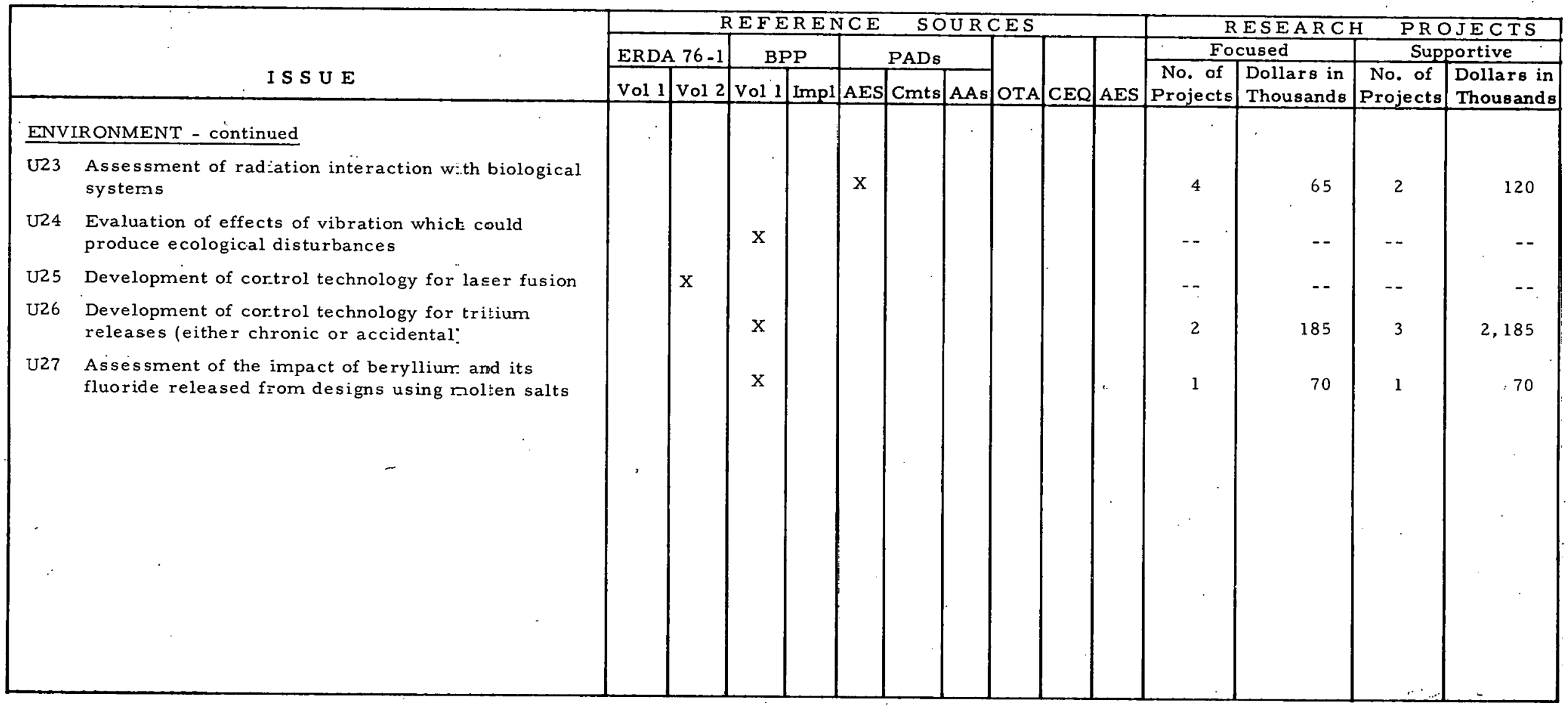




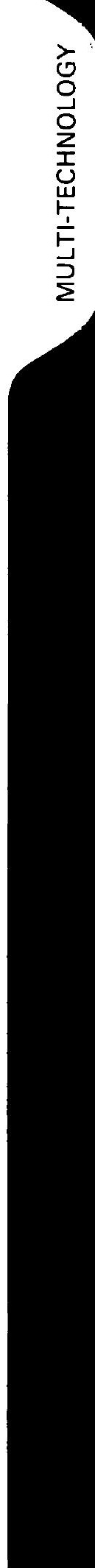


Planned research having applicability to several energy technologies and without focus on a specific technology has been classified as "Multi-technology". As shown in Table 13-1 the Overview and Assessment activities which include envircnmental data integration; policy analysis; social, cultural, and economic impacts at local, regional, and national levels are highly Multi-technology oriented and make-up the largest fraction of the planned Mult--technology budget. A substantial level of Multi-technology oriented health and environmental effects research is also planned.

The compliation of environmental issues from the referenced sources found that these issues were addressed in terms of specific energy technologies. Therefore, no listing of Multi-technology oriented issues is included in this section. The research focused on Multi-technology objectives shown in Table 13-1 has been correlated with the environmental issues listed in other "energy-specific" sections of this report. It has been included in the supportive research column of tables in all sections where issues appeared to which the planned research is addressed. 
TABLE 13-1. MULTI-TECHNOLOGY RESEARCH SUMMARY

\section{Subprogram}

Overview and Assessment

Health and Biological

Environmental

Physical and Technological.

Education and Training

Environmental Control Technology

Safety, Standards, and Compliance

TOTAL

\begin{tabular}{ll} 
Research & Projects \\
\hline Number of & Dollars in \\
Projects & Thousands \\
\hline
\end{tabular}

56

20,584

73

16,106

158

18,846

40

5,782

5

1,965

11

1,614

39

$\underline{\underline{382}}$

$-6,470$

71,367 


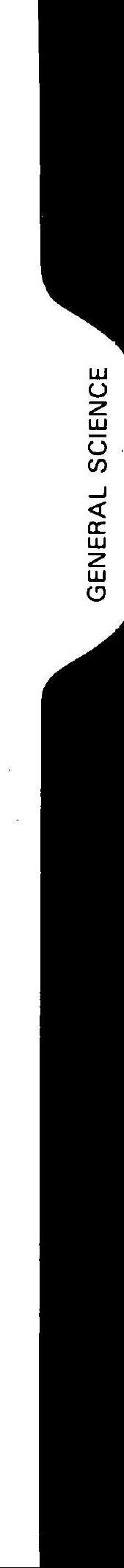


The Ganeral Science portion of the planned FY 78 AES program encompasses research not directly related to energy technology development. This research provides basic knowledge and a foundation essential for the conduct of other energy-related RD\&D. General Science research is conducted within the Biomedical and Environmental Research Division. A subprogram level summary of the planned research is presented in Tajle 14-1.

Since this research is not directly relatable to energy technology development it has not been possible to include it in the correlation with energy-related environmental is sues tabulated in preceding sections. Correlation of the planned General Science program with specific research needs was not attempted as a part of the reported effort. 
TABLE: 14-1. GENERAL SCIENCE RESEARCH SUMMARY

\section{Subprogram}

Metabolic, pathophysiological, and embryotoxic effects on experimental animals

Detection and characterization of damage in physiological, cellular. and molecular systems

Genetics

Basic atmospheric, tezrestrial, and marine processes

Basic physical and technological studies

Characterization, measurement, and monitoring

\begin{tabular}{ll} 
Research & Projects \\
\hline $\begin{array}{l}\text { Number of } \\
\text { Projects }\end{array}$ & Dollars in \\
\hline
\end{tabular}

14

1,662

100

13,141

46

3,400

6

236

8

1,184

2

515

$\underline{\underline{176}}$

$\underline{\underline{20,138}}$

.

TCTAL 


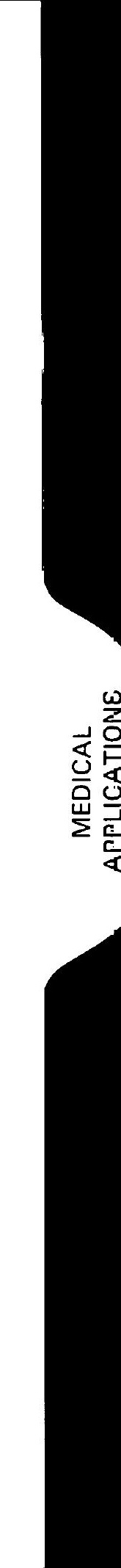




\section{SECTION 15}

\section{MEDICAL APPLICATIONS OF NUCLEAR TECHNOLOGY}

Research in this area is a continuation of work conducted by the former Atomic Energy Commission. It includes stidies to discover, develop, and perfect new technology, procedures, and medical devices to provide unique applications of radiation and radionuclides in the diagnosis and treatment of human diseases.

A summary of the planned funding for the Medical Applications activities in FY $7 \dot{8}$ is presented in Table 15-1. These planned projects have not been correlated with statements of environmental issues in other sections since those issies did not include medical applications, needs, and problems. 
TABLE 15-1. NEDICAL APPLICATIONS OF NUCLEAR TECHNOLOGY SUMMARY

\section{Subprogram}

General Use of Nuclear Technology in Medicine

Radioisotope Development

Development of Radicpharmaceuticals

Clinical Applications

Stable Isotopes

Medical Device Development

Radiation Damage in Biological Systems

Measurement Technoìogy

TOTAL
Rese a r ch

Projects

Number of Dollars in

Projects

10

Thousands

8

8

28

3

I

1

$\underline{8}$

$\underline{\underline{67}}$
3,310

2,596

1,818

8,679

742

175

16

933

18,269 